\title{
Gazi Süleyman Paşa Vakfi'nın Mali Tarihi ve 17. Yüzyılda Trakya Tarımsal Ekonomisi
}

\author{
Financial History of the Waqf of Süleyman Pasha and \\ Agricultural Economy in 17th-century Thrace
}

\section{Kayhan ORBAY *}

$\ddot{O} z$

Süleyman Paşa'nın Bolayır'da kurduğu vakıf bütçe imkanları bakımından Trakya bölgesinin en büyük vakıflart arasindadır. Vakfin kentsel gelirleri de bulunmakla birlikte ana gelir kaynağını Doğu Trakya bölgesindeki tarımsal topraklar oluşturmaktadır ve vakfin gelir ve giderleri bölgesel tarımsal koşullardaki değişimlere duyarlıdır. Bu çalışma vakfin 17.yy'ın ilk yarısina ait muhasebe defterleri üzerinden mali durumunu izlemektedir ve 17.yy Balkan ekonomisini incelemeyi amaçlayan daha kapsaml bir projenin parçasıldır. Vakfin mali analizi Süleyman Paşa vakfinın incelenen dönem içinde bir gelir kaybına uğramadığını ve derin bir mali kriz yaşamadlğın göstermektedir. Ancak bölgesel tarımsal koşulları kötüleştiren klsa-dönemli gelişmeler ile vakıf gelir kaynakların tahrip eden afetlerin mali darllklara neden olduğu görülmektedir.

Anahtar kelimeler: Osmanl, Süleyman Paşa, vakıf, mali tarih, tarımsal ekonomi, Trakya

\section{Abstract}

The waqf of Süleyman Pasha in Bolayır was among the largest waqf institutions in Thrace. The waqf held urban-based revenue sources. However, it derived the major part of its income from agricultural holdings in the Eastern Thrace. Therefore, rural revenues of the waqf were sensitive to the adverse changes in the regional agircultural conditions. This study examines the waqf account books pertaining to the first half of the seventeenth century and reveals the financial history of the waqf. It is part of a wider project dealing with the economic history of Balkans in the 17th century. The financial analysis of the waqf shows no decline in

\footnotetext{
Yrd. Doç. Dr., Orta Doğu Teknik Üniversitesi, Tarih Bölümü, korbay@metu.edu.tr.
} 
the waqf revenues or a deep financial crisis in the examination period. However, local developments affecting the agricultural production and natural disasters damaging the waqf properties led to short-term financial distress.

Keywords: Ottoman, Süleyman Pasha, waqf, financial history, agricultural economy, Thrace

Sultanlar, vezirler ve yüksek mevki sahibi devlet görevlileri tarafından kurulan büyük vakıflar, şehirlerin iktisadi ve ticari yaşamında mühim bir yer tutan, şehrin kültürel, mimari dokusunu tespit eden kurumlardır. Bu vakıflar iktisadi faaliyetleri, sağlık, eğitim ve dini hizmetleri ve hayır işleri ile Osmanlı tarihinin en merkezi kurumsal oluşumları içindedir. $\mathrm{Bu}$ nedenle sultan ve vezir vakıfları kurumsal tarihin en zengin çalışma alanlarından birisidir. Aynı zamanda, kendilerine düzenli gelir temin eden geniş tarımsal arazileri, dükkanları, haneleri ve hamamları ile yaygın kentsel mülkleri olan sultan ve vezir vakıfları benzeri büyük vakıfların mali analizleri, bölgesel iktisadi gelişmeleri görmemize olanak vermektedir. Yerel ekonomiye tesir eden iktisadi gelişmeler veya sosyal çalkantılar bu vakıfları da etkilemektedir. Deprem, yangın veya sel gibi afetler, kuraklık, salgın hastalık, köylünün toprağı bırakarak kaçmasına veya mahsulün talan olmasına sebeb olan isyanlar vakıfların maliyesini sarsabilmekte, vakıf hizmetlerini aksatabilmektedir. ${ }^{1}$

Sultan Orhan'ın oğlu Gazi Süleyman Paşa, Trakya'da hem kentsel hem de kırsal kaynaklardan gelir temin eden ve bölgesel ekonomiyi yansitan büyük bir vakfi Gelibolu'da kurmuştur. ${ }^{2}$ Bu vakfın mali tarihi, Doğu Trakya'nın ekonomik tarihine katkı yapmak açısından iyi bir araştırma konusudur. Vakıf daha önce Tevfik Güran tarafından çalışı1mıştır. ${ }^{3}$ Güran

$1 \mathrm{Bu}$ etkilere değinen çalışmalar içerisinde veba salgınının vakıf hamam gelirlerine tesiri hakkında bkz., Ronald C. Jennings, "Pious Foundations in the Society and Economy of Ottoman Trabzon, 1565-1640. A Study Based on the Juridical Registers 'Şer'i Mahkeme Sicilleri' of Trabzon", Journal of the Economic and Social History of the Orient, vol. XXXIII, 1990, 271-336. Depremlerin vakıfların faaliyetleri ve gelirleri üzerinde etkilerini ele alan bir çalışma için bkz., Kayhan Orbay, "Financial Consequences of Natural Disasters in Seventeenth-Century Anatolia: A Case Study of the Waqf of Bâyezîd II", International Journal of Turkish Studies, vol. 15, no. 1-2, 2009, 63-82.

2 Bu vakfın vakıfnamesi için M. Tayyib Gökbilgin, Edirne ve Paşa Livası, İstanbul, Üçler Basımevi, 1952, zeyl, 216-220. Sonradan yazılan bir vakfiye sureti için Ekrem Hakk1 Ayverdi, "Gaazi Süleyman Paşa Vakfiyesi ve Tahrir Defterleri", Vakıflar Dergisi, VII, 1968, 19-28.

3 Tevfik Güran, Ekonomik ve Mali Yönleriyle Vakıflar, Istanbul, Kitabevi, 2006. Ayrıca Hicri 891 ve 892 yıllarına ait iki muhasebe defteri Barkan tarafindan tamamen translitere edilmiştir, Ömer Lütfi Barkan, "Edirne ve Civarındaki Bazı İmaret Tesislerinin Yıllık Muhasebe Bilançoları", Türk Tarih Belgeleri Dergisi, I/2, 1964, s. 336-344. Ayrıca bkz., Gökbilgin, Edirne ve Paşa Livası, s. 165-167 ve Ayverdi, "Gaazi Süleyman Paşa Vakfiyesi”. 
vakıf muhasebe defterlerini kullanarak vakfin genel gelir ve gider rakamlarını elde etmiş ve uzun dönemli bir mali analiz yapmıştır. Bu çalışma ise vakfin mali durumu ile daha detaylı bir biçimde ilgilenecek ve daha kısa bir dönem kesiti altında yerel ekonomideki gelişmelerin vakıf maliyesine yansımalarını inceleyecektir.

Tarih yazımında, bu çalışmada ele alınan 17.yy'ın ilk yarısı yaygın isyanlar, nüfus hareketleri, kırsal yapıda çözülme ve bunların sonucu uzun dönemli bir iktisadi kriz dönemi olarak değerlendirilmektedir. Bu çalışmada vakfın mali analizi öncelikle Doğu Trakya bölgesinin tarımsal iktisadi tarihine katkı yapmayı amaçlamaktadır. Ancak bu amacın ötesinde, bu çalışma Trakya bölgesinin 17.yy'ın ilk yarısında tarımsal iktisadi tarihine yönelik daha kapsamlı bir çalışmanın adımlarından birisidir. Aynı zamanda, bu çalışmada ulaşılan ilk sonuçlar Anadolu'daki büyük vakıfların iktisadi gelişimleri ile bir karşılaştırma yapma imkanı verecektir. ${ }^{4}$

Gazi Süleyman Paşa vakfi bir hamam, bir kervansaray ve ona bitişik dükkanlar ile çarşı dükkanlarına sahiptir. Ancak gelirlerinin büyük kısmını Doğu Trakya'daki tarımsal topraklardan elde etmektedir. Vakıf muhasebe defterlerinden elde edilen ana gelir ve gider kalemleri ile ilgili veriler çalışmanın sonunda sunulan tablolara alınmıştır. Hamam ve ona bitişik dükkanlar kiraya verilmektedir ve muhasebe defterinde 'aylik gelirler' ('ani'l-müşâherât) girişi altında kaydedilmişlerdir. Kervansaray ve dükkanları ise iltizama verilmektedir ve bu nedenle diğer iltizam gelirleri ile birlikte kaydedilmiştir. Buna uygun olarak, sadece hamam ve ona bitişik dükkanlardan gelen gelir tablolarda kira geliri olarak yansıtılmıştır. Kervansaray ve diğer dükkan gelirleri ile değirmen gelirleri de her ne kadar iltizam gelirleri içinde yer alsa da ayrı olarak verilmiştir.

Vakfın mali durumu, gelirler ve giderler ayrımıyla ve onyıllık dönemler altında incelenecektir. İlk dönem elimizde 17.yy'a ait en erken tarihli defter olan 1604 yılı muhasebe defterinden başlamaktadır. ${ }^{5}$ Bu defterdeki kayıtlar vakfın gelir ve giderlerinin ayrıntılı görülmesi amacıyla daha teferruatlı

4 Suraiya Faroqhi, "A Great Foundation in Difficulties: or some evidence on economic contraction in the Ottoman Empire of the mid-seventeenth century", Revue D'Histoire Magrebine, 47-48, 1987, 109-121; idem, "Agricultural Crisis and the Art of Flute-Playing: The Wordly Affairs of the Mevlevi Dervishes (1595-1652)", Turcica, XX, 1988, 43-69; Kayhan Orbay, "16. ve 17. Yüzy1llarda Bursa Ekonomisi: Sultan Çelebi Mehmed Yeşil İmaret'inin Mali Tarihi (1553-1650)", A.Ü. Osmanl Tarihi Araştırma ve Uygulama Merkezi (OTAM) Dergisi, no: 22, 2007, 125-158; idem, "Financial Development of the Waqfs in Konya and Agricultural Economy in the Central Anatolia (Late $16^{\text {th }}-$ Early $17^{\text {th }}$ Centuries)", Journal of the Economic and Social History of the Orient, bastlacak.

5 MAD 5451. 
aksettirilmiştir. Sonraki dönemler çalışmada daha toplulaştırılmış biçimde aktarılmıştır.

\section{4-1610 Dönemi}

\section{Gelirler}

Tablo'da da görüldüğü üzere, 1604 / 1012-13 yılında vakfın toplam geliri (asl-ı mâl) yaklaşık 609.000 akçadır. Bu toplam gelirin 126.000 akçası aslında önceki mali yıldan devreden bütçe dengesidir ('an bakiyye-i muhâsebe-i sene-i mâziyye). Devreden bütçe dengesi önceki dönem sonunda vakfın kasasında kalan nakit akçayı içerdiği gibi tahsil edilememiş gelirleri yani vakfın alacaklarını da içerebilir. Gerçekten de devreden bu alacaklardan 27.000 akça cari mali yıl içinde yani 1604 y1lında tahsil edilmiş ve defterin başında kaydedilmiştir. Örneğin bunun içinde iki y1l önceden kalan 5.000 akçalık hamam gelirinin tahsili kaydı bulunmaktadır.

1605 / 1013-14 yılında ise toplam gelir rakamı 665.000 akçaya yükselmiştir. Geçen yıldan kalan alacak olmadığından ve daha önceki yıllara ait alacaklar içinden de bir miktar geçen yıl içinde toplandığından cari döneme devreden toplam tahsil edilemeyen gelir miktarı 98.752 akçaya düşmüştür. Buna önceki yıl sonunda kasada kalan 474 akça nakit eklenince önceki y1ldan devreden bakiyye 99.226 akça olarak kaydedilmiştir. Muhasebe defterinde asl-ı mâl terimi ile ifade edilen toplam gelir rakamını vakfin mali durumunun göstergesi olarak almamak gerekir. Çünkü bu rakam devreden alacakları, peşin tahsilatları ve borçlanmaları da içerir. Örneğin 1607 / 1015-16 y1lında, toplam gelir 875.000 akçaya yükselmiştir. Ancak bunun 139.000 akça kadarlık mühim bir kısmı önceki yıldan devreden bakiyyedir ve tahsil edilmeyen gelirleri içermektedir. Dolayısı ile biriken alacakları da içeren devreden bakiyyenin artışı ile birlikte toplam gelirin artması vakfin mali durumunun iyiye gittiğini değil tersine tahsilat güçlükleri yaşadığını göstermektedir. 1607 yılına ait defter bu alacaklardan bir kısmının tahsiline dair kayıtları "minhâ tahsîl şode" başlığı altında vermektedir. Buna göre H. 1009 y1lından kalan 8.000 akça kadar, H. 1010 yılından 6.000 akçaya yakın, H. 1011 yılından 24.000 akça kadar ve H. 1014 yılından 40.000 akçaya yakın alacak tahsil edilmiştir. Bu rakamlar bize vakfin önceki yıllarda ciddi bir tahsilat güçlüğü yaşamadığını göstermektedir. Sadece bir önceki yıldan kalan alacak miktarı yüksektir ki onun da 40.000 akçası cari y1l içinde tahsil edilmişdir. 1610 / 1018-19 mali dönemi sonunda toplam gelirin 228.000 akça kadarlık önemli bir kısmı baki kalmıştır yani cari dönem sonunda tahsil edilememiştir. Ancak bu durum muhasebe döneminin bir tam yılı kapsamamış olmasından kaynaklanmaktadır. 
1604 yılında vakıf, mukataa bölgelerinden birinden, gelecek yılın iltizam bedeline mahsuben 97.500 akçayı peşin olarak tahsil etmiştir ve defterin başında bunu ('an akça-i pişin) kaydetmiştir. ${ }^{6}$ Peşin iltizam bedeli tahsilatları yıllık bütçeyi gelir tahsilatları öncesinde rahatlatan ve satın alımlar için vakfa nakit sağlayan önemli bir imkandır. 1605 yılında ise 17.500 akça kadar bir meblağ Gelibolu'daki hamamın H. 1014 ile H. 1017 yılları arasında üç buçuk yıllık kirası karşılığı olarak ve hamamın tamir ve termimi amacıyla peşin olarak tahsil edilmiştir. 1606 yılında mukataa bedellerinden peşin olarak 41.000 akça toplanmıştır. Bunun 24.000 akçası Mürefte mukataasının bedelinden alınmıştır ki mültezim vakfın mütevellisidir, 17.000 akçası ise Ereğlice mukataasının bedelinden peşin olarak Ereğlice reayası tarafından Darüssaade Ağası'na elden teslim edilmiştir. Bir bakıma vakfın Darüssaade Ağalığı Hazinesi'ne teslim edeceği akçalar doğrudan reaya tarafından ödenmiştir. 1607 yılında ise 56.000 akça mukataa bedeli peşin olarak tahsil edilmiştir.

Vakıf 1606 yılında ayni borçlanmaya da gitmiştir. 'Ani'l-istikrâz kaydı altında kiler ve imaret ihtiyacı için 540 kile buğday istikraz olunmuştur. Bunun 140 kilesi vakıf reayasından 400 kilesi ise Dergah-1 Ali çavuşlarından Mehmed Çavuş'dan istikraz edilmiştir.

\section{Cari Dönem Gelirleri}

Cari dönem gelirleri deyimi ile vakfın önceki yıllardan devreden bütçe fazlası ve alacakları ile sonraki yıllara mahsuben aldığı peşin veya borç meblağların tümü hariç olmak üzere, vakfın sadece mevcut gelir getirici mülklerinden cari mali dönem içinde elde edeceği gelirler ifade edilmektedir. Vakfin 1604 yılında sadece cari dönem gelir kaynaklarından gelen gelirleri 386.000 akçadır ('ani'l-mahsûlât). Bunun içinde mukataa gelirlerinin yanı sıra Gelibolu'daki iki dükkan (252 akça) ile Gelibolu'daki hamamdan (5.000 akça) gelen 5.252 akçalık kira gelirleri ('ani'l-müşâherât) de bulunmaktadır. ${ }^{7}$ Defter çeşitli mukataalardan toplamı 100.000 akçayı aşan ve önceki mütevelli tarafından tahsil edilen kısmi peşin tahsilatlar kaydetmektedir. Ancak bu meblağ cari dönem geliri rakamında içerilmemektedir.

1605 yilında ise cari dönem gelirlerinin 598.500 akça seviyesine yükseldiğini görüyoruz. Bu meblağ önceki y1l alınan 97.500 akçalık peşin

Gelibolu bölgesinde yer alan Mürefte, Kirasiye, İstarine, Arablu ve Çengerli mukataası.

7 Barkan'n yayınladığı muhasebe defterlerinde vakfın Bolayır'da 6 bab dükkanı olduğu görülmektedir, Barkan, "Edirne ve Civarındaki Bazı İmaret Tesislerinin Yıllık Muhasebe Bilançoları", s. 337. 
bedeli içermemektedir. 1606 yılında cari dönem gelirleri 559.000 akça seviyesine gerilemiştir ki bunun yaklaşık 40.000 akçası tahsil edilemeden kalmıştır. Bu alacak bir sonraki sene yani 1607'de tamamen tahsil edilmiştir. Hamam peşin bedelle kiraya verildiğinden ve kira bedeli alınarak evvelce deftere kaydedildiğinden cari döneme gelir kaydedilmemiştir.

1607 y1lında cari dönem gelirleri 680.000 akçaya yükselmiştir. Bunun sadece 27.000 akçası cari dönem içinde tahsil edilememiştir. 1609 yılında cari dönem gelirlerinin 586.000 akça olarak kaydedildiğini görüyoruz. Gelibolu'daki hamam ve ona bitişik dükkanlar "“ani'l-müşâherât” girişi altında hâlî olarak kaydedilmiştir. 1610 yılında cari dönemden kaynaklanan gelirler 569.000 akça kadardır. Önceki yıl olduğu gibi hamam ve ona bitişik dükkanlar hâlî kalmıştır.

\section{Mukataa Gelirleri}

Vakfın 1604 yılında iltizam usulü ile işlettiği gelir kaynakları ('ani'lmukâta ât) toplam 377.000 akça tutmaktadır. İltizama verilen değirmenlerden elde edilen 5.760 akça ve kervansaraydan gelen 700 akça bu meblağın içindedir. En büyük mukataa bölgesi 200.000 akçaya iltizama verilen ve Gelibolu bölgesinde yer alan Mürefte, Kirasiye, İstarine, Arablu ve Çengerli mukataasıdır. Nefs-i Bolayır'ın bâd-i hevâ vergisinin toplanması 12.000 akçaya ve vakıf köylerinden aynı verginin toplanması 22.000 akçaya iltizama verilmiştir. Bir noktayı belirtmek gerek: Mukataa gelirleri defterde kaydedildiği miktar ile alınarak diğer gelir kayıtları ile birlikte toplandığında toplam gelir rakamının üzerinde çıkmaktadır. Bunun nedeni önceki mütevellinin zaten tahsil etmiş olduğu ancak cari mali yıla ait olan gelirlerin de hesaplanarak toplam mukataa gelirleri içinde kaydedilmesi, buna karşıllık toplam gelir hesabının içine alınmamış olmasıdır.

1605 yılında mukataa gelirleri 366.000 akça olarak kayıtlıdır ve çalışmanın sonunda verilen tablolara da bu şekilde geçirilmiştir. En büyük mukataa birimi 210.000 akçaya yükselen bedeli ile yine Gelibolu bölgesinin Mürefte ve diğer yerleşimlerinden oluşan az yukarıda değinilen mukataasıdır. Bu mukataanın bedelinin 97.500 akçası önceki yıl peşin alınmıştır. Dolayısı ile toplam mukataa gelirleri aslında 460.000 akçanın üzerindedir. Bazı iltizamların gelirleri artmıştır ancak en mühim farklılık önceki yıl kaydı bulunmayan Ereğlice mukataasının 55.000 akça bedel ile kaydıdır. $\mathrm{Bu}$ önceki yıla nazaran mukataa gelirlerindeki artışın ana nedenidir.

1606 yılında mukataa gelirleri 464.500 akça civarına yükselmiştir. Birkaç mukataa bölgesinden tahsil edilemeyen görece küçük meblağlar ile 
toplamda 31.000 akça tahsil edilememiştir. Mürefte ve birçok diğer yerleşimden oluşan mukataa bölgesi ayrıştırılarak iltizam edilmiştir. Böylece Mürefte 100.000 akça, Arablu ve Çengerli 45.000 akça, Kirasiye 31.000 akça ve İstarine 33.000 akça bedel ile iltizama verilmiştir.

1607 yılında alınan peşin mukataa bedelleri harici iltizam bedelleri toplamı 419.500 akçadır. Önceki yıl 1607 yılına mahsup olmak üzere peşin alınan bedeller ile birlikte hesap edilirse ${ }^{8} 460.500$ akçalık iltizam geliri olacaktır. 1609 yılı mukataa gelirleri 423.000 akça civarındadır. Bir önceki yılın muhasebe defteri bulunmadığından vakfın önceki yıl peşin bedel tahsil edip etmediğini bilemiyoruz. Cari yıldaki mukataa kayıtları peşin tahsilata dair bir kayıt içermiyor. Cari yılda mukataa gelirlerindeki azalış ise Ereğlice mukataa bölgesinin yer almamasından kaynaklanmaktadır. İki yıl önce, 1607 'de Ereğlice 60.000 akça bedel ile iltizam edilmiştir. 1610 yılında mukataa gelirleri 442.000 akçaya çıkmıştır. Ereğlice mukataa bölgesinin kaydı yine görünmemektedir.

\section{Emanet Usulü İle Tahsil Edilen Nakdi Gelirler}

Vakfın önemli miktardaki gelirleri emanet usulü ile işletilmektedir ('an mahsûl-i kurâ-yi mezburân ki ber-vech-i emânet zabt kerd end). Bu gelirin nakdi toplanan kısmı cizye ve resm-i çift ile diğer kırsal vergilerden kaynaklanmaktadır. Bu biçimde vakıf 1604 ve 1605 yıllarında Bolayır ve köylerden yıllık yaklaşık 78.000 akça kadar nakit gelir toplamıştır.

1604 ve 1605 yıllarının her biri için cizye gelirleri 43.819 akça, resm-i çift ise 17.555 akçadır. Vakıf 176 kişiden, mükellef başına 9 akça olmak üzere 1.584 akça bennâk vergisi, 172 kişiden kişi başına 6 akça olmak üzere 1.032 akça mücerred vergisi toplamaktadır. Geriye kalan nakit gelirler kervansaray dükkanları, değirmen, bağ ve koyun vergileri benzeri vergilerden gelmektedir. 1606 yılında emanet usulü ile toplanan nakdi gelirlerin küçük bir kısmı ve ayni gelirlerin bir kısmı toplanamamıştır. 1610 y1lına gelindiğinde vakfın cizye geliri 43.721 akça, çift-resmi geliri 18.497 akça, bennâk vergisi 115 neferden 1.035 akça ve mücerred vergisi 123 neferden 738 akça olarak gerçekleşmiştir.

Nakit gelirlerin büyük kısmı 40.842 akça ile Bolayır'dan toplanmaktadır. $\mathrm{Bu}$ gelirlerin ve aynı zamanda emanet usulü ile toplanan ayni gelirlerin Hicri 959 tarihinde ayrıntılı kayıtları Maliyeden Müdevver

8 Mirefte ve çevresi için 24.000 ve Ereğlice mukataası için 17.000 akça olmak üzere toplam 41.000 akça. 
tasnifinin 2 numaralı defterinde bulunmaktadır. Bu defter E. H. Ayverdi tarafindan Gazi Süleyman Paşa vakfiyesini tetkik ettiği bir çalışma vesilesi ile gözden geçirilmiştir. ${ }^{9}$ Vakıf sayıları muhtemelen otuzu bulan değirmene sahiptir. Bunlar 1604 ve 1605 yıllarında yıllık 5.760 akçaya iltizama verilmiştir. Bunlardan ayrı olarak vakfin köylerdeki değirmenlerden 428 akçayı değirmen vergisi olarak topladığını görüyoruz.

Vakfın topladığı kırsal vergilerin kayıtları vakfın kendisi tarafindan tutulan bazı defterlerde fevkalade teferruatlı olarak kaydedilmiştir. MAD 15488 kodlu Hicri 1011 tarihli (1602-03) defterin kapağında "defter-i rüsûm 'an cibâyet-1 Birgos be-zabt-1 Hâcı Mûsa 'an zamân-1 fahrü'l-akrân Fethullah Bey el-mütevelli-i evkâf-1 mezbûre el-vâki' sene 1011" yazmaktadır. Defterin giriş kısmında ise "defter-i resm-i çift ve bennâk [ve] mücerredân ve gayruhu ve cibayet-i Birgos ma' tevâbi'ihâ" yazmaktadır ve defter bu yerleşimlerden Süleyman Paşa vakfına ait vergi gelirlerini vermektedir. İçeriği ile ilgili teferruatı göstermesi için Birgos köyü kayıtları şöylece özetlenebilir; On hane toplam onaltı çiftlik büyüklükte yer tasarruf etmektedir ki resm-i çift 22 akçadır. Beş hane yarımşar çift tasarruf etmektedir ki resm-i nim-çift 11 akçadır. Yedi bennâk mükellef başına 9 akça resm-i bennâk ödemektedir. On mücerred altışar akça resm-i mücerredân ödemektedir. Ayrıca resm-i bağat, kovan ve bostan toplanmaktadır. Birgos köyünden sonra ona yakın diğer bazı köylerin de kayıtları verilmiştir. Defterin sonunda cizye-i gebrân, resm-i çift, bennâk, mücerredân ve diğer vergilerin toplam bedelleri kaydedilmiştir. Defterde son kayıt "cemân rüsûm ve "âdet-i ağnâm ve cizye ve gayruhu; meblağ 6.570 [akça]"dır. ${ }^{10}$

1604 / 1012-13 tarihli muhasebe defterinde Birgos köyünün emanet usulü ile işletilen gelirler ile ilgili kısımdaki kaydı "cibayet-i Birgos be-zabt-1 Hâcı Mûsa câbî, 'ani'-n nukûd 6.573 [akça]” şeklindedir. Hacı Musa câbiyân ve kâtibân kadrosu içinde yevmi 3 akça ile câbî̀-i Birgos olarak kaydedilmiştir. Ayrıca Mustafa yevmi 3 akça ile kâtib-i Birgos olarak kayıtlıdır.

Defter-i Rüsûm (H. 1011) ile Muhasebe defterinin (H. 1012-13) kayıtları arasında aşağıya aktarılan küçük farklar bulunmaktadır.

9 Ayverdi, "Gaazi Süleyman Paşa Vakfiyesi". MAD 2 kodlu defterin kapağında "defter-i evkâf-1 merhûm Gâzî Süleymân Paşa bin Sultân Orhan tâbe serâhu der mahrûse-i Gelibolu" yazmaktadır. Defter ilk olarak Gelibolu kazasına bağlı Bolayır'da vergileri vakfa birakılan mahallelerin vergi mükelleflerini kaydetmektedir.

10 Defterde ilk hesaplama üzerinde bir düzeltme yapılarak 6.570 yazılmıştır. Aslında her bir vergi cinsinden tahakkuk eden bedellerin toplamı deferdeki kayıtlara göre 6.587 akçadır. 


\begin{tabular}{|l|l|l|}
\hline & Defter-i Rüsum & Muhasebe Defteri \\
\hline Resm-i çift & 116,5 zevc (?) için 2.563 akça & 2.562 \\
\hline Resm-i bennâk & 180 akça (neferen 20 fî 9 akça) & 180 akça (neferen 20 fî 9 akça) \\
\hline Resm-i mücerredân & 166 akça' ${ }^{11}$ (neferen 26 fî 6 akça) & 156 akça (neferen 26 fì 6 akça) \\
\hline Resm-i bâgât & 393 akça & 390 akça \\
\hline Resm-i kovan & 129 akça & 129 akça \\
\hline Resm-i besâtîn & 76 akça & 76 akça \\
\hline Mukâta'a-i zemîn & 2 akça & 2 akça \\
\hline 'Adet-i ağnâm & 558 akça & 558 akça \\
\hline Resm-i cizye-i gebrân & 2.520 (36 nefer) & 2.520 (hâne 36 fî 70) \\
\hline
\end{tabular}

Bu kayıtlardan birkaç sonuç çıkarılabilir. Birincisi muhasebe defterinde sadece karye-i Birgos kaydı bulunmasına rağmen kaydın altında verilen gelirler Birgos ile civarındaki köylerin toplam gelirleridir. İkincisi vakfin kendi katib ve cabisi her yıl Birgos ve civarındaki köyleri tahrir etmekte, vergi ve mahsul miktarını tespit etmektedir. Bunları defter-i rüsûm başlıklı bir müsvedde deftere kaydetmektedir. Muhasebe defterinde "ber-vech-i emânet zabt" kaydı bulunmasına karşın vergiler vakfın kendi maaşlı cabisi tarafindan toplanmakta ve vakfa teslim edilmektedir.

Hicri 1011 tarihli MAD 15462 ise defter kapağı ve girişine nazaran Malkara'ya bağlı Karayahşi köyü ile defter içeriğine nazaran ilaveten Ballu İlyas, Ak Sakal, Kara Koç, (...), Bunak köyleri için yukarıda anlatılan aynı vergi kayıtlarını içermektedir. Hicri 1021 tarihli MAD 15358 ise Gelibolu'ya bağlı Doğanarslan köyü ile Mesih Beğ çiftliği'nden gelen nakdi gelirleri kaydetmektedir. Hicri 1022 tarihli MAD 15353 ve MAD 15357 ise Malkara kazasına bağlı vakıf köylerinden, aynı tarihli MAD 15359 diğer bazı vakıf köylerinden nakdi toplanan vergilerin kayıtlarını içermektedir.

\section{Ayni Tahsil Edilen Gelirler}

Emanet usulü ile toplanan bu nakdi gelirlere ilaveten vakıf ayni gelirler de toplamaktadır. 1604 yılında vakıf 3.251 kile buğday, 757 kile arpa, 131 kile pirinç ile birlikte yulaf, burçak, nohut gibi ürünlerden toplamda 5.878 kile tahsilat yapmaktadır. Cari yılda bunun 5.636 kilesi tahsil edilmiş ve 242 kilesi baki kalmıştır.

Defter kayıtlarında ilginç bir nokta vardır. Emanet usulü ile toplanan ayni gelirlerin toplam miktarı 'ani'l-gallât kaydı altında fiilen tahsil edilen

11156 akça olması gerekirdi. 
ve edilemeyen kısımları (makbûz ve bâkî) yazılarak verildikten sonra her bir ürün için miktar kayıtları verilmiştir. Bu kayıtlarda ürünün ismi altında 'ani'l-asl ma 'a tefâvüt yazmaktadır. ${ }^{12}$ Öyle anlaşllıyor ki Edirne kilesi ile toplanan mahsul muhasebede İstanbul kilesine çevrilerek kaydedilmiştir.

Defter daha sonra her bir köyden tahsil edilecek ürün miktarlarını köy adları altında ayrıntılı vermiştir. İlk kayıt nefs-i Bolayır'a aittir. Burada ani'n-nukûd başlığı altında kaydedilen nakdi gelirlerden sonra 'ani'l-gallât girişi altında önce buğday ve sonra diğer ürünlerin tahsil edilecek miktarları kayıtlıdır. Buğday miktarı 687 kile olarak yine "asl" ve kile farkı toplamı ('ani'l-asl ma'a tefâvüt) olarak verilmiştir. 'Ani'l-asl 458 kiledir. 'An tefâvüt ise beher 2 kile fi 1 kile kaydının arkasından 229 kile olarak verilmiştir. $\mathrm{Bu}$ durumda 1 Edirne kilesi 1,5 İstanbul kilesine denk olarak hesap edilmiştir. Ancak arpa, yulaf, burçak, nohut, pirinç ve diğer ürünler için beher 4 kile fi 1 kile (sonraki defterlerde beher müdden fi 5 kile kaydı da görülmektedir) kaydına istinaden bu oran söz konusu ürünlerde 1'e 1,25 seviyesindedir. Fark 1605, 1606 ve 1607 yıllarında da aynı oranlar üzerinden alınmıştır. 1609 yılında ise buğday için fark (tefâvüt) miktarı müd başına 12 kileye, diğer ürünler için müd başına 7 kileye yükselmiştir. ${ }^{13}$

1605 y1lında ise toplam mahsul tahsilatı 5.311 kileye inmiştir. 1606 y1lında 3.372 kile kadar buğday, 971 kile kadar yulaf ve 912 kile kadar arpa emanet usulü ile tahsil edilmek üzere kaydedilmiştir. 1607'de toplam tahsilat 7.500 kileyi geçmektedir. 5.000 kilenin üzerinde buğday, 1.100 kile kadar arpa ve yine o kadar yulaf tahsil edilmiştir. 1609 yllında ise toplam 11.000 kileye yakın hububat tahsili olmuştur. Bu artışın kısmen kile farkı (tefâvüt) oranının yükselmesinden kaynaklandığı açıktır. Bunun 7.300 kile kadarı buğday mahsulüdür. Arpa tahsilatı 1.300 kileyi geçmiş ve yulaf ise 2.000 kileye yaklaşmıştır. Bu miktarlar cari yılda mahsulün de pek bol olduğunu göstermektedir. 1610 yılında toplam tahsilat 7.500 kile kadardır. Bunun 5.139 kile kadarı buğday, 1.318 kilesi yulaf ve 817 kilesi arpadır.

Vakfın aşar tahsilatı için de aynı nakdi gelirler için tutulan defter-i rüsûm benzeri ayr1 müsvedde defterleri bulunmaktadır. Hicri 1022 tarihli MAD 15354 böyle bir defterdir. Defter kapağında "defter-i 'aşâr-1 hubûbât-1 mütenevvi'a-1 'an cibâyet-i Tatarlar" ve defter girişinde "defter-i 'aşâr-1 hubûbât-1 mütenevvi'a-1 cibâyet-i Tatarlar tâbi'-i kazâ-i Malkara evkâf-1 merhûm ve mağfûrün leh Şehzâde Süleymân Paşa-i Gâzî ibn Sultân Orhan tâbe serahumâ der zamân-1 fahrü'l-akrân 'Alî Efendi el-mütevelli be-'imâreti kasaba-i Bolayır el-vâki“ sene 1022” yazmaktadır. Defter vakfa bağlı

12 Kelimeyi yardım manasına te 'âvün olarak okumak dahi mümkündür.

13 Bu durumda buğday için 1 Edirne kilesi 1,6 İstanbul kilesine denk gelmektedir. 
Tatarlar ile Malkara kazasındaki diğer bazı köylerden köylünün mahsul miktarını ve tahsil edilen öşr vergilerini kaydetmektedir. Defter sonunda toplam mahsul ve öşr miktarları verilmektedir. ${ }^{14} \mathrm{Bu}$ tür defter-i 'aşârhubûbât defterleri ile az yukarıda bahsedilen ve nakdi gelirlerin takip edildiği defter-i rüsûm defterleri her yıl için yazıldıkları izlenimini vermektedir. Arşivlerde böyle defterlerin daha tam seriler halinde bulunması ihtimali vardır. Bu durumda yerleşimlerde mükellef sayıları, toplam mahsül miktarları benzeri değerli bilgiler yıl-yıl izlenebilecektir.

\section{Diğer Gelirler}

Diğer vakıf gelirleri ('an emvâl-i müteferrike) olarak 1604 yılında 33.926 akça kaydedilmiştir. Bu gelirin tamamı vakıf anbarından satılan tahıldan elde edilniştir. 635 kile yulaf satışı tek başına 15.000 akçadan fazla getirmiştir. Hicri 1011 yılına ait MAD 15486 kodlu defter anbardan hububat satışı işlemlerinin kayıtlarının nasıl tutulduğunu göstermektedir. Defter kapağında "defter-i fürûht-1 hubûbât-1 mütenevvi'a be-esmân-1 muhtelife 'an zamân-1 Fethullah Bey el-mütevelli be-'imâret Bolayır el-vâki' sene 1011", defterin girişinde ise "defter-i merhûm Şehzâde Süleymân Paşa-yı Gâzî hazretlerinin bin onbir senesinde vâki' hubûbât-1 mütenevvi'anın fürûhtlarıdır ki zikr olunur" yazmaktadır. Bu "defter-i fürûht-1 hubûbât" anbardan hububat satışı ile elde edilen gelirlerin detaylı kayıtlarını içermektedir. $\mathrm{Bu}$ kayitlar muhasebe dönemi sonunda ana muhasebe defteri yazilırken derlenmekte ve kısaltılarak 'an emvâl-i müteferrike girişi altında kaydedilmektedir. Aynı zamanda kiler ve anbar muhasebesi için tutulan ve ana muhasebe defterine iliştirilen defter veya ek kayıtlara özet olarak geçirilmektedir. İlk kayıt olan "fürûht-1 hınta" altında vakfın onüç kez farklı fiyat seviyelerinden buğday sattığını görmekteyiz. Kile başına fiyat 52 akça ile 100 akça arasında değişmektedir.

1605 yllında ise diğer gelirler 99.233 akçaya yükselmiştir. Bunun nedeni 54.100 akça toplam bedel ile kilesi 100 akçadan anbardan satılan 541 kile buğdaydır. Önceki mali yıla nazaran vakfin toplam gelirlerindeki artışın bir diğer temel nedeni de diğer gelirler kalemindeki bu artış olarak görünmektedir. 1606 yılında vakıf buğday, arpa ve yulaf satamadığından diğer gelirler kalemi 15.000 akçanın altında gerçekleşmiştir. 1607 yılında ise diğer gelirler 184.000 akçaya yaklaşmıştır. Vakıf kilesi 60 akçadan 821 kile buğday satmış ve 50.000 akçaya yakın gelir elde etmiştir. Ancak diğer gelirlerdeki artışın esas nedeni anbardan kilesi 20 akçadan satılan 5.500 kile

14 Hicri 1022 tarihli MAD 15167, MAD 15352, MAD 15355 ve MAD 15361, Hicri 1032 tarihli MAD 15908 ile Hicri 1046 tarihli MAD 15889 da bu kayıtların diğer vakıf köyleri için tutulduğu defterlerdir. 
tuzdur ki bu satış tek başına 110.000 akça gelir getirmektedir. 1609 yılında ise diğer gelirler 89.000 akça civarındadır. Bunun 70.000 akça kadarı 1.710 kile buğday satımından gelmektedir. 1610 yılında vakıf 533 kile buğday, 1.192 kile yulaf ve 452 kile arpa satarak 56.000 akçaya ulaşan bir ilave gelir temin etmiştir. Bazı yıllarda diğer gelirler kalemi yıllık bütçeyi destekleyen önemli bir kaynak olabilmektedir. Ancak bu tarımsal koşulların iyi olmasına, vakfın anbarından satabileceği fazla hububatın birikmesine ve elbette fiyatların da elverişli olmasına bağlıdır. Dolayısı ile diğer gelirler kalemi tarımsal koşullar ve fiyatlar ile değişen istikrarsız bir gelir kalemidir.

\section{Giderler}

\section{Maaş ve Aylık Ödemeleri}

Toplam giderler maaş ödemeleri, mutfak harcamaları ve sair harcamalar kalemlerinden oluşmaktadır ve 1604 yılında 510.356 akçadır. Aynı yıl maaş ve aylık ödemeleri toplamı 219 kişi için 208.170 akçadır. Vakfın daimi çalışanları (vazîfehârân) olan 181 kişiye yıllık 145.770 akça maaş ödemesi yapılmaktadır. Geriye kalan 38 kişi kendilerine toplam 62.400 akça ödeme yapılan zevâ'idhârândır.

Maaş ve aylık ödemeleri için büyük vakıflar ayrı defterler tutarlardı. Süleyman Paşa vakfina ait Hicri 1004 tarihli bir "defter-i vazîfehârân" MAD 6778 kodu ile mevcuttur. Defterde vakıf çalsşanları ile zevâ'idhârân nakdi ve ayni maaş ve aylıkları ile listelenmektedir. MAD 5017 kodlu bir diğer defter Hicri 1011 yılına aittir ve vakıfda sene içinde maaş ve aylık ödemelerinin nasıl izlendiğini gösteren bir defterdir. Defter girişinde "defter-i vazîfehârân ve cerrehârân ve zevâîdhârân" yazılıdır. ${ }^{15}$ Defterde önce kadrolar altında çalışanların isimleri, maaş seviyeleri ve maaşlarını teslim aldıkları aylar daha sonra zevâ 'idhârân aylıkları ve son olarak cerrehârâna ödenen ayni maaşlar kayıtlıdır. MAD 4994 içinde de Süleyman Paşa Vakfı çalışanlarına ait kayıtlar vardır. Sanıyorum bu vakıfda değil merkezi dairelerde tutulan ve diğer bazı vakıfların çalışanlarının yanı sıra Süleyman Paşa vakfının da çalışanlarını Hicri 1030 yıllarına geri gidecek şekilde kaydeden ve yirmi yılı aşkın bir süre kadrolardaki değişimin kaydedildiği ve izlendiği bir defterdir.

1605 y1lında toplam giderler ve maaş ödemelerinde önemli bir değişiklik görülmemektedir. 510.733 akçalık toplam giderlerin altında

15 Vazîfehârân vakıfda vazifeli, daimi istihdam edilen ve nakdi maaş alan görevlilerdir. Cerrehârân ise vakıf görevlilerinden nakdi maaşları yanında aynî maaş da alan veya sadece aynî maaş alan kimseler ile kendilerine aynî aylık bağlanmış olan hak sahipleri ve muhtaç kimselerdir. Zevâ'idhârân ise vakıfdan nakdi aylık alan hak sahibi, emekli ve muhtaç kimselerdir. 
sırasıyla ödenen ve ödenmeyen meblağları ifade etmek üzere edâ şode 457.075 akça ve edâ ne-şode 53.658 akça kaydı düşülmüştür. Maaş ve ayliklar tam olarak ödenmiştir. Ödenmemiş giderler mutfak tüketimi için veresiye alınan gida mallarına aittir.

1606 y1lında toplam giderler 529.000 akçaya çıkmıştır. Bunun 192.000 akça kadarı maaş ve aylık ödemelerine aittir. 1607 yılında toplam gider rakamı 682.000 akçaya yükselmiştir. Bunun 25.000 akçası ödenmeden kalmıştır. 1610 yılında gider hesapları da muhasebe dönemi gibi sadece sekiz aylık bir dönemi kapsadığından toplam giderler 326.000 akça kadardır. Sekiz aylık dönem için maaş ödemeleri 166 çalışan için 100.000 akça kadardır.

Vazife sahipleri ondört ayrı kadro altında listelenmiştir. İlki 20 görevlinin yer aldığı cemấât-i müteferrika-i evkaf kadrosudur. Vakıf mütevellisi de günlük 60 akça maaşı ile burada kaydedilmiştir. Bu kadrolar altında istihdam edilenlerin sayıları bu çalışmanın sonuna eklenen tablolardada yer almaktadır. İkinci kadro otuzbir kişilik eczâhanân kadrosudur. Sonraki başlık 11 kişi ile musabbihîn kadrosuna aittir. Süleyman Paşa'nın türbesinin hizmetlileri olan 12 kişi hademe-i türbe-i şerif başlığ 1 altında kayıtlıdır. 5 kişi devirhânân câmi 'i şserif kadrosundadır. İmaret görevlileri 25 kişidir ve bunlar içinde şeyh-i imaret, anbarî, kilarî, bevvâb, kâseşûy, ferrâş, tabbâh, ser-tabbah gibi çalışanlar bulunmaktadır. Vakıf, gelirlerin toplanması ve kaydı için 21 kişilik bir câbiyân ve kâtibân kadrosu istihdam etmektedir. Geriye kalan yedi kadroda 56 çalışan yer almaktadır ve bunlar Gelibolu, Lapseki, Kavak, Malkara, Ferecik, Şabhane ve Vize'de bulunan yedi ayrı camiinin çalışanlarını listelemektedir.

Vakıf, 1604 yılında bütçeden aylık alan 38 kişilik bir zevâ'idhârân kesimini de desteklemektedir. Bu kimselere yıllık 62.400 akça ödeme yapılmıştır. 1605 yılında 35 kişiye 60.000 akça kadar, 1606 yılında ise sadece 18 kişiye toplam 37.000 akça kadar bir ödeme yapılmıştır. Zevâ'idhârân içinde listelenen 20 kişiye ise ödeme yapılmamıştır. Defter sonunda yer alan bir muhasebe kaydından bu ödemelerin karşılığ meblağın Darüssaade Hazinesi'ne aktarıldığını öğrenmekteyiz.

\section{İmaret Harcamaları}

Vakfın en büyük gider kalemini imaret harcamaları oluşturmaktadır. Mutfak giderleri (harc-1 matbah) için vakıf 1604 yılında yaklaşık 255.000 akça harcamıştır. Bu meblağın en mühim kısmı 126.000 akça ile et satın alımına gitmiştir. Daha sonra 51.500 akça ile pirinç, 45.000 akça ile sadeyağ en büyük mutfak harcaması kalemleridir. Mutfağa bunların dışında bal, tuz, safran, badem, nişasta, üzüm ve erik alımı yapılmaktadır. Ayrıca misafirlere 
verilen ziyafet için vakıf çeşitli gıda malı alımlarına 7.500 akça ödemiştir. Odun satınalımı da mutfak harcamaları arasında 13.000 akçaya varan önemli bir gider kalemi olarak yer almaktadır. 1605 yılında ortaya çıkan 254.000 liralık mutfak giderinin 158.400 akçası et satınalımı içindir ki bunun 51.040 akçası ödenmemiştir (edâ ne-şode). Ayrıca misafir ve eşrafa ziyafet için alınan 5.071 akçalık etin de 2.618 akçası ödenmemiştir. 1606 yılında mutfak harcaması 286.000 akçaya yükselmiştir. Bunun nedeni sadeyağ ve pirinç satın alım miktarındaki artış olarak görünmektedir.

1607 yılında 25.000 akçası bir miktar et alımına karşılık ödenmeden kalmak üzere mutfak harcamaları için 377.000 akça kadar bir ödeme yapılmıştır. Harcamalardaki bu ciddi artışın esas nedeni 52.000 akçaya ulaşan 4.650 kile tuz satın alımı ile önceki yıl kaydı olmayan ve cari yılda ise 28.000 akçaya yaklaşan buğday satın alımıdır. Vakıf bu yıl ilginç bir biçimde önce 4.650 kile tuz satın almış ve daha sonra anbardaki tuz ile birlikte 5.500 kile tuz satmıştır. Alım ve satım fiyatlarındaki fark dolayısı ile vakıf bu işlemden 58.000 akça kazanç elde etmiş görünmektedir. 1609 yılında imaret harcamaları 293.000 akça olarak gerçekleşmiştir. 1610 yılında sekiz ay içinde mutfak giderleri için 171.000 akça kadar ödenmiştir.

\section{Sair Harcamalar (ihrâcât-ı sâire, el-ücârât, el-meremmât)}

Sair harcamalar (ihrâcât-1 sâire) kalemi vakfın her türlü cari giderlerini içermektedir. Bu kalem içinde özellikle mum, kandil ve fitil alımı benzeri aydınlatma giderleri düzenli olarak yer almaktadır. Sair harcamalar 1604 yılında yaklaşık 12.000 akçadır. 1605, 1606, 1607 ve 1609 yıllarında sirasıyla $15.000,18.000,23.000$ ve 20.000 akça seviyelerine çıkmıştır.

Vakıf ayrıca gıda maddelerinin nakliyesi, odunun taşınması, buğdayın anbara çekilmesi, değirmene taşınması ve unun değirmenden anbara nakli için 1604 yılında yaklaşık 18.000 akça hammaliye ücreti ödemesi yapmıştır (el-ücârât). 1605-1607 arasında ve 1609-1610 yıllarında sair harcamalar ve ücret ödemeleri bütçeyi etkileyecek önemde bir değişiklik göstermemiştir.

1604 yılında tamirat giderleri (el-meremmât) vakıf binaları, hamam ve değirmenlerin düzenli bakım ve onarımı için harcanan 9.500 akçadan oluşmaktadır. 1605 'de tamirat giderleri neredeyse 20.000 akçaya yükselmiştir ki bunun yaklaşık 18.000 akçası Gelibolu hamamının onarımına ayrılmıştır. Hatırlanacağı üzere bu tamiratın bütçesi için hamam üç-buçuk y1llık kira bedeli olan 17.500 akça peşin alınarak kiraya verilmişti. 1606 y1lında tamirat giderleri gerileyerek 7.300 akça civarına inmiştir ve 1607 yılında 9.500 akça, 1609 yılında 8.500 akça, 1610 yılının sekiz aylık dönemi için 4.700 akça kadar gerçekleşmiştir. 


\section{Ayni Ödemeler, Nakit Teslimleri, Alacaklar ve Bütçe Dengesi}

1604 y1lında, giderlerden sonra toplam gelirden 99.226 akça kalmıştır. Ancak bu meblağ 98.752 akça ile neredeyse tamamen tahsil edilemeyen gelirlerden oluşmaktadır. Bunun 50.227 akçası önceki yıldan kalan alacaklardır. Muhasebe cari dönemden kalan alacak kaydetmemiştir. Böylece vakıf kasasında nakit olarak sadece 474 akça kalmıştır. 1605 yılında ise giderlerden sonra vakıf yaklaşık 208.000 akça kaydetmektedir. Ancak bundan sonra yeniden mevacib ödemesi kayıtları başlamaktadır. Önceki mali dönemde ana muhasebe defteri içine alınmayarak kiler muhasebesinde kaydedilen aynî maaş ödemeleri bu yıl ana defterde yer almıştır. Önceki yıl olduğu gibi 1605 yılında da arpa ve yulaf aynî maaş ödemelerinde kullanılırken, müteferrike-i evkâf, kâtibân ve câbiyân ile zevâ'idhârâna yapılacak aynî buğday ödemesi yerine nakit bedelleri olan 109.500 akçalık bir ödeme yapılmıştır.

Böylece 1605 yılında geriye yaklaşık 99.000 akça kalmıştır ki neredeyse tamamı alacaklardan oluşmaktadır. Önceki yıl da kayıtlı olduğu gibi söz konusu alacağın 50.000 akçalık kısmı H. 1011 yılından kalmadır. Böylece vakıf kasasında sadece 60 akça kalmaktadır.

1606 yılında harcamalardan sonra 169.000 akça kadar kalmıştır. Bunun 42.480 akçası Darüssaade Hazinesi'ne teslim edilmiştir. Bu meblağ aslında bu mali yılda ref' olunan yirmi zevâ 'idhârânın aylıklarıdır. Bu nakdi teslimat sonrası 126.000 akça kadar kalmıştır. Bunun 138.681 akçası alacaktır, başka bir deyişle bütçe açı̆̆ı oluşmaktadır. Hicri 1011 yılından 50.000 akça kadar alacak devam etmektedir. Cari yıldan yani Hicri 1014 y1lından da 40.000 akça kadar alacak kalmıştır. Vakıf ez-ziyade harc ani'l-asl kaydı ile 11.841 akçalık bir bütçe açı̆̆ kaydetmiştir.

1607 yılında harcamalardan sonra vakfin elinde 218.000 akça kadar kalmıştır. Bunun 45.000 akçası teslîm be-hizâne-i âmire-i Dârü's-sa 'âde 'an zevấ'id-i evkâf-ı mezbûre kaydı ile Darüssaade Ağalığı Hazinesi'ne teslim edilmiş ve ayrıca 82.000 akça civarında borç ödemesi yapılmıştır. $\mathrm{Bu}$ borçların 79.000 akça kadarı önceki mütevelli zamanından kalan ödenmemiş maaşlardan ve kasaplara borçlanılan 53.000 akçalık veresiye et satın alımından kaynaklanmaktadır. $\mathrm{Bu}$ nakit teslimat ve borç ödemelerinden sonra vakfın elinde 91.000 akça kadar kalmıştır. Bunun ise 88.000 akça ile neredeyse tamamı tahsil edilemeyen gelirlerden oluşmaktadır ki defterde Hicri 1006 yılı öncesine giden alacaklar kayıtlıdır. Sonuçda vakfın kasasında 2.784 akça nakit kalmıştır.

1609 yılında harcamalara ait kayıtlardan sonra hiç alacak kaydı düşülmemiştir. Böylece vakıf kasasında 32.085 akça ile mali yılı kapamış 
görünmektedir. 1610 yılında harcamalardan sonra 285.000 akça civarında bir baki kaydı verilmiştir. Bu meblağdan 57.000 akça Darüssaade Ağalığ 1 Hazinesi'ne teslim edilmiştir. Bunun 40.000 akçası H. 1017 yılı ödemesi olarak teslim edilmiş 17.000 akçası ise ber-mûceb-i mektûb-ı şerîf kaydı ile teslim edilmiştir. Böylece vakıf geriye kalan 227.789 akçayı sahhü'l-bâkî başlığ1 altına kaydetmiş ancak hemen arkasından tamamen aynı tutarı derzimem başlığı altına alarak bu meblağın tümünün tahsil edilemeyen gelirlerden oluştuğunu kaydetmiştir. Alacakların böyle ciddi bir miktara ulaşmasının esas sebebi muhasebe döneminin sekiz ayı kapsaması dolayısı ile mültezimlerin vakıf ile sözleştikleri tüm meblağı henüz teslim etmemiş olmalarıdır.

\section{Anbar ve Kiler Hesapları}

Ana muhasebe defterine aynî gelir ve giderleri gösteren kiler muhasebeleri eklenmiştir. 1604 yılı kiler muhasebesinde ilk kayıt buğday ve un içindir. Cari dönemde kilere giren buğday ve un miktarı yaklaşık 4.300 kiledir. Bunun yaklaşık 1.100 kilesi önceki dönemden devretmiştir. Ancak anlaşıldığ kadarıyla bu miktarlar tamamen anbar mevcudundan oluşmamaktadır. Tahsil edilemeyen veya henüz vakıf anbarına teslim edilmemiş miktarları da içermektedir. Geriye kalan 3.200 kile vakıf köylerinden cari dönem içinde toplanmıştır. Benzer kayıtlar diğer gıda malları için de verilmiştir. Arpa ve yulaf kayıtları, bu ürünler vakfın ana gelir ve giderleri içinde yer aldığından önemlidir. Kayıtlı arpanın neredeyse tamamı, 700 kile cari dönemde toplanmıştır. Yaklaşık 900 kile yulaf önceki dönemden devretmiştir. 1.400 kile kadar ise vakıf köylerinden tahsil edilmiş ve 100 kile yulaf piyasadan satın alınmıştır.

Kiler muhasebesi dönem içinde sarf edilen miktarları ve sonrasında kilerde kalan mevcutları da kaydetmektedir. Unun büyük kısmı, 1.700 kilenin üzerinde bir miktar fodula ekmeği pişirmede kullanılmıştır. Toplam 3.500 kileye yakın buğday tüketilmiştir. Buğdayın bir kısmı çorbada kullanılmış ve 1.700 kileden fazlası un elde etmek üzere öğütülmüştür. Yaklaşık 1.500 kile buğday ise vakıf çalışanlarının aynî maaş ödemelerine gitmiştir. Arpa ve yulaf da aynî ödemelerde kullanılmaktadır. Belirli miktarlarda tahıl pazarda satılmıştır ki satım miktarları ile buradan elde edilen gelirler hatırlanacağı üzere ana muhasebe defterinde diğer gelirler bahsinde de kayıtlıdır.

1604 yılı sonunda hesaplara göre alacak ve anbarda mevcut olarak kayıtlı buğday 810 kile kadardır. Bunun sadece 44 kile kadarı anbarda mevcuttur ve geriye kalanı alacak (der-zimem) olarak kaydedilmiştir. 70 kile arpanın 20 kilesi anbarda kalanı ise alacakdır. 970 kile yulafın ise tamamı 
alacak olarak kayıtlıdır. Bu alacakların büyük kısmı henüz vakıf anbarına teslim edilmemiş olarak cabilerin zimmetinde görülmektedir.

1605 yıl1 kiler muhasebesine göre kilere giren buğday 4.000 kile civarındadır. Bunun önceki yıl gibi 3.200 kile kadarı cari yılda vakıf köylerinden toplanmıştır. 1.900 kilesi un yapılmış ve bu un ekmek yapımında kullanılmış, 541 kile buğday ise satılmıştır ki bu satımdan elde edilen 54.100 akçalık gelir ana muhasebe defterinin diğer gelirler kısmında da kayıtlıdır. Arpa ve yulaf ayni maaş ödemelerinde kullanılmıştır.

1605 yılı sonu kiler hesaplarına göre 917 kile buğdayın 300 kilesi anbarda mevcut kalanı ise alacakdır. 944 kile yulafın ise sadece 20 kilesi mevcuttur, kalan miktarlar ise alacak olarak kayıtlıdır.

1606 y1lı anbar hesaplarına göre cari yılın buğday hasılatı 3.370 kile civarına çıkmış, sarf edilen ve ayni olarak ödenen buğdaydan sonra anbarda 144 kile kadar buğday kalmıştır. 1607 yılında ise cari dönem buğday mahsulatı 5.100 kile üzerindedir ve sarf edilen miktardan sonra kilerde 1.600 kilenin üzerinde buğday kalmıştır. Ancak bunun fiilen 1.000 kile kadarı anbardadır, geriye kalan 600 kile kadar buğday tahsil edilemeden kalan miktardır. 1610 yılı hesaplarına göre sekiz aylık dönem sonunda kilerde 3.500 kileden fazla buğday kalmıştır.

\section{Genel Mali Görünüm (1604-1610)}

Vakfın 1604 yılında iltizam ve toplam gelirinin düşük olmasının bir nedeni Ereğlice mukataa bölgesinin kayıtlı olmamasındandır. İkinci olarak ise diğer gelirler kaleminin ana kaynağı olan hububat satışlarının düşük olmasıdır. Bunun nedeni ise hububat mahsulünün az olması, önceki dönemlerden de tahsil edilememiş aynî gelirler bulunması ve vakıf anbarında satılacak hububat olmamasıdır. $\mathrm{Bu}$ tarımsal üretimde bir düşüşe işaret etmektedir. 1605 yılında da vakfın elde ettiği aynî mahsul yüksek olmamakla birlikte hububat fiyatları da tarımsal üretim düşüşünü gösterir şekilde yüksektir ve bu yüksek fiyat seviyesinden hububat satış1 vakfa iyi bir gelir bırakmıştır. Diğer taraftan 1604 ve 1605 yıllarında görülen ve 100.000 akça civarında bulunan tahsil edilememiş gelirler kaydına bakarak -bu birikmiş alacakların yıllara göre dökümü elimizde bulunmamakla birlikte- ve vakfın 1606 yılında buğday cinsinden borçlanmak zorunda kaldığını hatırlayarak vakfın 1600'lerin başında nakdi ve aynî gelirlerde bazı tahsilat güçlükleri yaşadığını söyleyebiliriz. Buna karşın, vakfın incelenen bu ilk döneminde iltizama verdiği tarımsal gelirlerinde vakfin mali durumunu cidden zora sokacak derecede bir düşüş veya tahsilat güçlüğü görünmemektedir. 
Güran tarafindan Süleyman Paşa vakfı muhasebe defterlerinden elde edilen fiyatlara bakarsak 1605 yılı ile sonrası karşılaştırıldığında buğday, arpa ve yulaf fiyatlarının önemli ölçüde düştügünü görebiliriz. ${ }^{16}$ Örneğin 1605 yılında buğdayın kilesi 100 akça iken 1607 yılında 60, 1609 yılında 41 akçaya inmiştir. Bu fiyat düşüşünün vakfın kırsal gelirinde de karşıllk bulması beklenirdi. Ancak eğer 1605 yılı fiyatların istisnai olarak yükseldiği bir yıl ise bu ani ve geçici fiyat artışının iltizam sözleşmelerine yansıtılmaması gayet doğaldır.

Vakfın bazı köylerinden vergiler emanet usulü ile toplanmaktadır ve bunların kaydı farklı ve detaylı tutulmuştur. Bolayır merkezi ile birlikte köyler tek tek başlıklandırılmış ve her birinden toplanan vergiler ayrı ayrı kaydedilmiştir. 1604 ve 1605 yıllarında öşr tahsilatı yıllık 5.000-5.500 kile aralığındadır ve vakıf 1606 yılında 540 kilelik buğday ile aynî borçlanmaya da gitmiştir ki bir y1l sonra bunun geri ödenmesi kaydı da yer almaktadır. 1607 yılı toplam öşr tahsilatı 7.500 kileyi geçmiş, 1609 yılında ise bir yandan artan kile farkı (tefâvüt) oranı ile birlikte 11.000 kileye yaklaşmıştır. 1610 yılında yeniden 7.500 kile seviyesine inmiştir. Bu kısa döneme elimizdeki fiyat verileri ile birlikte baktığımızda 1607 ve 1609 yıllarının istisnai bir verimli hasat ve bolluk yılları değil, tersine tarımsal üretimde normalleşme yılları olduğunu görüyoruz. Başka bir deyişle, 1604-06 yılları tarımsal üretimde bir düşüş dönemi olarak görünüyor.

Vakfın diğer gelirler kaleminin ('an emvâl-i müteferrike) büyüklüğü öncelikle vakfın anbardan hububat satışlarına bağlı olarak azalmakta veya artmaktadır. Bazı yıllarda bu gelir kalemi bütçeyi destekleyen çok önemli bir kalem olarak ortaya çıkmaktadır. Örneğin, 1605'de 100.000 akça, 1607'de 184.000 akça, 1609'da 90.000 akça kadar gelir anbardan satışlardan elde edilmiştir. Bu gelir olağan olarak hububat satışından gelmekle birlikte 1607 yılında vakfın yaptığı bir işlem çok dikkat çekicidir. Vakıf bu yıl kilesi 20 akçadan 150 kile tuz satın almış ve 3.000 akça ödemiş, ayrıca ortalama fiyatı yaklaşı 11 akçadan 4.500 kile tuz satın alarak 48.625 akça, böylece toplamda 51.625 akça ödemiştir. Kiler hesabı da 1.222 kile tuzun mevcut olduğunu, 4.650 kile tuzun satın alındığını böylece toplam mevcudun 5.872 kile olduğunu kaydetmektedir. Yine kiler hesabı bu tuzun 90 kilesinin sarf edildiğini, 5.500 kilesinin satıldığını, muhasebe defteri ise kilesi 20 akçadan satılan tuzun 110.000 akça gelir getirdiğini kaydetmektedir.

Toplam giderler maaş ödemeleri, mutfak harcamaları ve sair harcamalar kalemlerinin seyri vakfin yaşadığ 1 bir mali darlığ 1 ve bunun fiile işleyişe etkisini verebilecek önemli bir göstergedir. Maaş ödemelerinde ciddi bir

${ }^{16}$ Güran, Ekonomik ve Mali Yönleriyle Vakıflar, s. 185. 
aksama görülmemekle birlikte 1606 yılından itibaren vakıftan aylık alan zevâ'idharân sayısının yarıya inmesi ilginçtir. 1606 y1lında ise sadece onsekiz kişiye toplam 37.000 akça kadar bir ödeme yapılmıştır. Zevâ'idharân içinde listelenen yirmi kişiye ise ödeme yapılmamıştır. Defter sonunda yer alan bir muhasebe kaydından bu ödemelerin karşılığ olan meblağın Darüssaade Hazinesi’ne aktarıldığını öğrenmekteyiz.

1604 ve 1605 yıllarında fiyatlar sonraki yıllara nazaran yüksek olmasına karşın bu yıllarda mutfak giderlerinin düşük olmasının nedeni satın alım miktarlarının görece az olmasından kaynaklanmaktadır. En önemli gider kalemi olan et, pirinç ve sadeyağ alım miktarlarında sonraki yıllarda hafif bir artış vardır. Zaman zaman buğday satın alımı yapıldığı da olmuştur. 1607 yılında ise istisnai bir tuz alımı yapılmıştır. Ancak temel olarak imaretin düzenli işlediği, yemek ve ekmek çıkardığı söylenebilir.

Sair harcamalar (ihrâcât-1 sâire) ve tamirat giderleri de incelenen bu ilk dönem içerisinde vakfın bütçesini etkileyecek veya bir mali darlığa işaret edecek bir değişim göstermemiştir.

1604 y1lında, önceki yıllardan ve özellikle Hicri 1011 yılından kalan alacaklarla birlikte 100.000 akçaya yaklaşan bir alacak ortaya çıkmıştır. Ancak cari yıldan kalan alacak yoktur. Kayıtlı alacaklar 1605 ve 1606 yıllarına da devretmiştir. Vakıf 1606 yılında Darüssaade Hazinesi'ne nakdi teslimat yapmıştır. Ancak tahsil edilemeyen gelirler yükselmiş ve bütçe 12.000 akça kadar açık vermiştir. 1607 yılında toplam alacak miktarı düşmüş, Darüssaade Hazinesi'ne nakdi teslimat yapılmış ayrıca bazı borçlar ödenmiştir. 1609 yılında dönem sonu vakfın kasasında kalan nakit 32.000 akça ile ilk kez kayda değer bir meblağa ulaşmıştır. 1610 yılında da vakıf Darüssaade Hazinesi'ne nakdi teslimat yapmıştır. Bu özet görünüm vakfın kısa süreli tahsilat düzensizliği yaşaması ve veresiye borçlanması, bütçe fazlası oluşturamaması ve hatta 1606 'da olduğu gibi açık vermesine rağmen Darüssaade Hazinesi'ne nakdi teslimatta bulunabildiğini, tahsilat güçlüğünün sürekli olmadığını ve alacakların üstüste birikmediğini de göstermektedir.

\section{1-1620 Dönemi}

\section{Gelirler}

İncelenecek ikinci döneme ait ilk defter 1611 / 1018-1021y1lını içine almakta ve onaltı aylık bir dönemi kapsamaktadır. Bu uzun dönem dolayısı ile toplam gelir rakamı yüksektir. Bu rakamın içinde önceki dönemden devreden yaklaşık 228.000 akçalık alacak da yer almaktadır ki defter gelirler kısmının başında bu meblağın tamamının cari dönem içinde tahsil edildiğinin kaydını vermektedir. Cari dönemden gelirler 660.000 akça, 
mukataa gelirleri ise 412.000 akça seviyesindedir kadardır. Bir kaç yıl aradan sonra Gelibolu hamamı sadece 3.000 akçaya kiraya verilmiştir.

Bir sonraki defter 1612 / 1021 yılına ait ve sekiz ayı kapsayan düzensiz bir defterdir. Bu nedenle toplam gelir rakamı düşükdür ve gelirlerin 157.500 akça kadarı tahsil edilemeden kalmıştır. Mukataa gelirleri yıllık sözleşme değerleri üzerinden 418.170 akça olarak kayıtlıdır. Kervansaray 600 akçaya iltizama ve Gelibolu'daki hamam 8.000 akçaya kiraya verilmiştir.

1617 / 1025-1027 yılı muhasebe defteri yaklaşık onbeş aylık bir dönemi kapsamıştır. 600.000 akça kadar bir toplam gelir rakamı kayıtlıdır. Bunun 86.500 akçası önceki yıldan devreden bütçe dengesidir ki alacakları da içermektedir. Bu meblağdan 78.000 akça kadar bir alacak cari y1l içinde tahsil edilmiş ve kayıtları defterin ilk kısmında "minhâ tahsîl şode" başlı̆̆ altında tutulmuştur. İltizam gelirleri 433.000 akça olarak verilmiştir.

1618 / 1027-1028 y1lı defteri bir tam y1lı kapsayan düzenli bir defterdir. Defter önceki dönemden devreden sadece 859 akça nakit ve 9.000 akçalık alacak kaydetmiştir ki bunun tamamı iki câbî ile eski mütevelli zimmetinde kalan paralardır ve cari dönem içinde tamamı tahsil edilmiştir. İltizam gelirleri 440.000 akça olarak verilmiştir.

1619 / 1028-1029 yılında vakıf üç ayrı mukataa bölgesinin H. 1029 yılı iltizam bedelleri için toplam 114.000 akça peşin tahsilat yapmıştır. Önceki dönemden devreden 7.000 akçalık alacak aynen kalmıştır. İltizam gelirleri 446.000 akçaya yükselmiştir.

1620 / 1029-1030 y1lı muhasebesi yaklaşık dokuz buçuk aylık bir dönemi kapsamaktadır. Önceki dönemden devreden bütçe dengesi 88.000 akça kadardır. Bunun 55.000 akçası vakfın kasasında nakit olarak mevcut, 33.000 akçası ise alacaktır. Alacakların önemli bir kısmı cari dönem içinde tahsil edilebilmiştir. Böylece önceki dönemlerden sadece 7.600 akça alacak kalmıştır. İltizam gelirleri 456.000 akça kadardır. ${ }^{17}$ Bunun 114.000 akçası önceki sene peşin olarak alınmıştır. 269.000 akça kadarı cari dönemde yeni mütevelli tarafından tahsil edilmiş, 103.000 akça kadarı ise baki kalmıştır. Ancak bu durum bir mali sıkıntıdan değil muhasebe dönemindeki düzensizlikten kaynaklanmaktadır.

\section{Emanet Usulü İle Tahsil Edilen Gelirler}

1611 ve 1612 yıllarında vakıf emanet usulü ile 75.000 akça civarında, 1617 yılında 79.500, 1618 ve 1619 yıllarında 77.000 akça kadar nakdi gelir

${ }^{17}$ Defterde hataen 486.270 akça olarak hesap edilmiştir. 
toplamıştır. Vakıf yerleşimlerinde nüfusu da bir derece gösteren vergi kalemlerinde ciddi bir değişim yoktur.

1611 yılında aynî toplanan gelirler 12.000 kile seviyesine çıkmıştır. Kile farkı (tefâvüt) oranı buğdayda yine müd başına 12 kile diğer ürünlerde müd başına 7 kiledir. Sonraki yıllarda bu kadar yüksek bir rakama ulaşılamamıştır. 1612 senesinde aynî tahsilat 6.000 kile kadardır. 1617 yılında ise 7.700 kile kadar aynî vergi toplanmıştır. 1618 yılında aynî gelir 7.500 kile, 1619 y1lında 8.330 kiledir. 1620 y1l muhasebesi tam bir y1l kapsamadığından ayni vergiler 4.480 kileye düşmüştür.

\section{Diğer Gelirler}

1611 y1lında diğer gelirler kalemi 169.000 akça ile önemli bir meblağa ulaşmıştır. En büyük katkıyı 131.260 akça ile anbardan satılan buğday ve 24.540 akça ile yulaf yapmıştır. Buğday satımının yapıldı ̆̆ 1 farklı fiyat seviyeleri de defterde verilmiştir. Buna göre buğday kile başına 12,5 akçadan 36 akçaya kadar dokuz ayrı fiyat seviyesinden satılmıştır.

1612 yılında sekiz aylık dönem için diğer gelirler kalemi 20.650 akçadır. 1617 yılı diğer gelirleri sadece 8.000 akçadır ve bunun tamamı vefat eden üç ayrı kimsenin muhallefatından gelmektedir. 1618 yılında 759 kile, 1619 yılında 1.238 kile hububat satıldığına dair kayıt bulunmaktadır. Bu satışlardan elde edilen gelirler önceki defterlerden farklı olarak 'an mahsûl-i bahâ-i gllâl başlığı altında sırasıyla 10.249 ve 30.827 akça olarak kayıtlıdır. Ayrıca bu yıllarda anbardan tuz satımı ile sırasıyla 10.000 ve 1.000 akça kadar gelir temin edilmiştir. 1620 yılının eksik hesap dönemi içinde mahsul az olduğundan anbardan satışlar da azdır ve sadece 11.000 akça kadar gelir elde edilmiştir.

\section{Giderler}

1611 yılında 182 daimi vakıf çalışanı için 233.000 akça ve 22 zevâ'idharân için 69.000 akça kadar bir ödeme yapılmıştır. Aynî maaş ödemeleri hak sahibi olan toplam 70 kişiye 1.968 kile buğday (200 kilesi evvelden kalan ödeme), 357 kile arpa ve 540 kile yulaf ile ödenmiştir. 1612 yılında ödemeler yedi aylık bir dönemi kapsadığından sadece 118.000 akça kadar bir ödeme yapılmıştır.

1617 y1lında onbeş aylık bir dönem için 298.000 akça kadar maaş ve aylık ödemesi yapılmıştır. Ayrıca 83 kişiye ayni olarak buğday, arpa ve yulaf ödemeleri yapılmıştır. Bunun otuzaltısı vakıf çalışanı değil zevâ'idharândır. Dolayısı ile aynî yardım alan zevâ'idharân sayısı kendilerine maaş bağlanmış olanlardan fazladır. Kaç kişinin hem nakdi hem de aynî yardım 
almakta olduğu kayıtlardan ayrıca tespit edilebilir. 1618 yılında nakdi maaş ve aylıklar için toplam 234.000 akça ödeme yapılmıştır. Ayrıca aynî maaş ve yardım alan otuzyedisi zevâ 'idharân geriye kalanı vakıf çalışanı olan seksen kişiye istihkakları dağıtılmıştır.

1619 yılında onüç aylık bir dönem için 254.000 akça kadar ödeme ve 79 kişiye aynî ödeme yapılmıştır. 1620 yılında dokuz aylık bir dönem için maaş ve aylıklar ödenmiş, çalışanlar aynî ödemelerini de alırken zevâ'idharânlara cari hesap dönemi içinde aynî ödeme yapılmamıştır.

1611 yılında ücret ödemelerindeki artış dikkate değerdir. Vakıf mahsulünün köylerden anbara, değirmene ve pazara nakli masrafları için ödenen hammal ve araba ücretleri 34.500 akça civarında tutmuştur. $\mathrm{Bu}$ artışın nedeni vakfın tahsil ettiği mahsul miktarındaki muazzam artıştır. 1611 yılı tamirat harcamalarının da 121.000 akça seviyesine firladığını görüyoruz. Vakıf anbar, türbe, hamam, değirmen ve üstlendiği diğer bazı tamiratlar yanında Bolayır, Gelibolu, Lapseki ve Kavak'ta camileri tamir ettirmiştir. 1612 yılı içinde de 46.000 akçaya yakın tamirat gideri oluşmuştur ki önceki yıl girişilen bazı onarımların devam ettiği görülmektedir.

1611 y1lında giderlerden sonra 41.000 akça kadar kalmıştır. Bunun 23.000 akçası, Darüssaade Ağası'nın gönderdiği mektup üzerine tek bir çalışanın ödenmeden kalan maaşları karşılığı olarak ödenmiş, 9.240 akçası ise önceki mütevellilerden Davud Çavuş'un vakıf için yaptığı et alımından kalan borca ödenmiş, geriye kalan meblağ vakfin çeşitli camilerindeki çalışanların ödenmemiş maaşlarına gitmiştir. Dönem sonunda nakit kaydı olmamakla birlikte vakıf anbarında 1.700 kile üzerinde buğday ve 383 kile arpa ile diğer ürünlerden kalmıştır.

1612 yılında giderlerden sonra önceki yıl sadeyağ satınalımından kalan yaklaşı 5.000 akçalık borç ödenmiş, ayrıca bazı kimselerin verilmemiş aynî maaşları karşılığ 1 olarak nakdi ödemeler yapılmıştır. Daha sonra 157.557 akçalık alacak listelenmiştir. Bu meblağın 14.500 akçası aslında câbiyân tarafindan tahsil edilmiş ama henüz vakfa teslim edilmemiş vergi gelirleridir. Böylece vakfın kasasında 782 akça nakit kalmış ve yeni mütevelliye teslim edilmiştir.

1617 yılında giderlerden sonra veresiye et alımından kasaba borçlanılan 2.880 akça ödenmiş ve 9.000 akça kadar tahsil edilememiş gelir listelenmiştir. Böylece vakfın kasasında 859 akça kalmıştır. 1618 yılında giderlerden sonra zevâ 'idharânlardan birinin ödenmemiş aynî maaşı karşılığ 1 olarak 12.620 akça ödenmiştir. Geriye kalan 7.000 akça alacak olarak kaydedilmiştir ve vakfın kasasında hiç nakit kalmamıştır. 1619 yılında ise 33.000 akçalık alacak kaydı verilmiştir. Dönem sonunda vakfin kasasında 
55.000 akça nakit kalmıştır. 1620 yılında hesap dönemi eksik olduğundan kalan alacaklar ile önceki dönemlerin alacakları birlikte 115.000 akça kadar tutmaktadır. Vakıf kesede 4.200 akça nakit ile dönemi kapamıştır.

\section{Genel Mali Görünüm (1611-1620)}

Ele aldığımız ikinci dönemde mali durumu izlemekte zorlandığımız boşluklar bulunmaktadır. Mevcut defterler gelirlerin tahsilatında hiçbir kayda değer düzensizliğe işaret etmemektedir. Gelibolu hamamı yeniden kira geliri getirmeye başlamıştır. Önce 3.000 akçaya iltizama verilen hamam sonraki y1llarda bedelini 8.000 akçaya yükseltmiş ve bu seviyeyi korumuştur. İltizam gelirleri ise dönem boyunca bir artış göstermiştir. Fiyatların durağan olduğu bu yıllarda iltizam gelirlerinin artması tarımsal ekonominin istikrarlı olduğunun göstergesi olarak alınabilir. Buna karşılık vakfın nakdi topladığı vergilerde bir artış görünmemektedir. Emanet usulü ile işletilen köylerden aynî toplanan mahsul miktarı konusunda ise net bir sonuç çıkarmak olanaklı değildir. İncelenen dönem içerisinde 1611 yılı açıkca çok bol bir hasat yılı olarak görünmektedir. Elbette istisnai bir yılın hasatı iltizam sözleşmelerine ve böylece mukataa gelirlerine yansımamakla birlikte, vakfin aynî hububat tahsilatı yükselmiş ve anbardan hububat satışları önemli bir gelir bırakmıştır.

Dönem boyunca imaretin çalıştığı, nakdi ve aynî maaşların ödendiği, zevâ 'idhârân kesimine de ödemelerin yapıldığı görülmektedir. Zevâ'idhârân mevcudunun dönemin başında düşük olduğu ve sonuna doğru yine otuz kişiye ulaştığı görülmektedir. 1611 ve 1612 yıllarında vakfın üstlendiği tamirat giderlerine bakarak bir yerel afetten şüphelebiliriz. Ancak bu durum vakfın bütçesinin elvermesi ile yerine getirilen onarımlardan da kaynaklanabilir. Vakıf mevcut defterlere nazaran dönem boyunca 1611 yılı dışında ciddi bir bütçe fazlası elde edememiştir. Bütçe fazlası oluştuğunda ise ertelenmiş maaş ve aylık ödemeleri ile evvelki veresiye alımların ödendiği görülmektedir. Darüssaade Ağalığı Hazinesi’ne ise nakdi teslimat yapılmamıştır.

\section{1-1630 Dönemi}

İncelenen üçüncü dönem 1622 / 1031 y1lına ait dört aylık eksik bir muhasebe defteri ile başlamaktadır. Defterin önceki dönemden devreden hesap dengesi kaydının meblağca düşük olmasına bakarak en azından bir önceki dönemde bir tahsilat güçlüğü olmadığını söyleyebiliriz. İltizam gelirleri 536.000 akça civarına yükselmiştir. $\mathrm{Bu}$ artışın esas nedeni Ereğlice'nin yeniden bir mukataa olarak 75.000 akça iltizam bedeli ile kayıtlarda yer almasıdır. Emanet usulü ile nakdi tahsil edilen gelirlerde 
önemli bir değişim yoktur. Defter sadece dört ayı kapsadığından gelirlerin yaklaşık 2/3'ü henüz tahsil edilmemiştir. Aynî tahsil edilen gelirlere dair ise hiçbir kayıt yoktur. Harcamalar da dört aylık bir dönemi kapsamaktadır. Defter sonunda yer alan alacak kayıtlarına bakıldığında vakfın Hicri 1027 ve 1029 yıllarından kalan 23.000 akça kadar alacağı olduğu görülmektedir ki bunun 19.000 akçası Kavak mukataasına aittir. Bu kayıtlar da ciddi bir tahsilat güçlüğüne işaret etmemektedir. Hesaplar dört ayda kesildiğinden cari döneme ait 379.570 akçalık alacak kaydı yer almaktadır.

İzleyen defter 1622-23 / 1031-1032 y1llarına ait sekiz buçuk aylık bir muhasebedir ki bir önceki defteri tamamlamaktadır. Bu defter H. 1027 y1lından kalan alacakların tamamının ve H. 1029 yilından kalan alacakların 5.500 akçasının tahsil edildiğini kaydetmektedir. Ayrıca, bir önceki eksik hesap döneminden kalan 379.000 akçalık alacağın tahsil edildiğini görüyoruz. Emanet usulü ile elde edilen aynî gelirler 5.000 kile kadardır. Bu miktar oldukça düşük bir mahsüle işaret etmektedir. Üstelik buğdayda Edirne ve İstanbul kilesi farkı (tefâvüt) müd başına oniki kileden yirmi kileye yani birebire yükseltilmiş, başka bir deyişle 1 Edirne kilesi 2 İstanbul kilesine denk hale getirilmiş, diğer ürünlerde ise (arpa, yulaf ve pirinç) oran müd başına yedi kileden on kileye çıkmış, başka bir deyişle 1 Edirne kilesi 1,5 İstanbul kilesine denk hesap edilmiştir. Maaş ödemeleri sekiz aylık bir dönemi kapsamaktadır. Bazı maaşlar örneğin müderris maaşı sadece iki ay ve ondokuz gün için ödenirken talebelerin maaşları hiç ödenmemiştir. Çalışanlara aynî ödemeler yapılmış ancak zevâ'idhârâna aynî ödemeler büyük ölçüde aksamıştır. 330.000 akçaya varan mutfak giderlerinin 140.000 akça kadarı ödenmemiştir. Vakıf pazardan ve çok yüksek fiyattan 480 kile kadar buğday satın almak zorunda kalmıştır. Buğdayın kilesi başına 130 akça ödenmiştir. Bir önceki dört aylık muhasebede ise buğdayın kilesi başına 220 akça ödendiğini ve 1619 yılında kile başına fiyatın 30 akça olduğunu gözönüne alırsak fiyatları ve vakfın elde ettiği mahsül miktarını da etkileyen bir tarımsal kötüleşme olduğunu ileri sürebiliriz. Vakıf sadece 10.500 akça alacak kaydederek kasada 170 akça nakit ile dönemi kapamıştır.

Maalesef izleyen defter 1625 / 1035 yılına ait yaklaşık beş aylık bir muhasebedir. Toplam gelir rakamı olan 148.094 akça tamamen önceki dönem muhasebe dengesine eşittir ki devreden bakiye nakit içermemekte, tamamen alacaklardan oluşmaktadır. $\mathrm{Bu}$ alacakların tamamı ise cari muhasebe dönemini bir tam yıla tamamlayan önceki muhasebe döneminden kalmıştır. $\mathrm{Bu}$ bize vakfın daha da önceki dönemlerden alacağının bulunmadığını gösterir. Dahası önceki eksik dönemden kaynaklanan 148.094 akçalık alacağın tamamı tahsil edilmiştir. Defter bunların tahsilatı dışında bir gelir kaydı vermeden yaklaşık beş aylık muhasebe döneminin kapsadığ 1 
giderlerin dökümüne geçmiştir. Hesaplar 1.883 akça bütçe açığı ile kapanmıştır.

İzleyen 1628 / 1037-1038 y1lına ait muhasebe defteri tam bir mali y1lı kapsamaktadır. Önceki yıldan devreden bütçe fazlası görünmemektedir. Başka bir ifade ile vakfın ne kasasında nakit ne de tahsil edilememiş alacağ 1 vardır. Cari dönemden kaynaklanan gelirler 559.000 akça kadardır. Bunun 479.200 akçası mukataa gelirlerinden gelmektedir ki Ereğlice yine bir mukataa bölgesi olarak iltizam edilmiştir. Bu daha önceki dönemlerden karşılaştırılabilir ilk kayda sahip 1622 y1lına göre ciddi bir düşüşü ifade etmektedir. İltizama verilen birçok tarımsal bölge ile gelir kaynaklarında düşüş vardır. Diğer gelirler kalemi sadece 9.050 akça getirmiştir. Emanet usulü ile toplanan nakdi gelirler 70.600 akça, aynî gelirler ise 6.737 kiledir. Vakfın nakdi maaş ve aylık ödemeleri ciddi bir değişim göstermemiştir. Ancak ifa edilmemiş aynî maaş ve aylık ödemeleri bulunmaktadır. Mutfak harcamaları önceki yıllara göre düşüktür. Bu kısmen fiyatlarda gerileme kısmen ise satınalım miktarlarında azalma ile açıklanabilir. Vakıf diğer cari giderler, ücret ödemeleri ve tamirat giderlerini yerine getirdikten sonra mali dönemi 7.606 akça fazla ile kapamıştır.

\section{Genel Mali Görünüm (1621-1630)}

Dönem boyunca elde edilebilen defterlerden görüldüğü kadarıyla vakıf bir tahsilat güçlüğü yaşamamıştır. İltizam gelirlerindeki artış temel olarak Ereğlice'nin bir mukataa bölgesi olarak vakıf gelirlerine katılmasındandır. Buna karşılık emanet usulü ile toplanan nakdi gelirler artmamış tersine hafif bir azalış göstermiştir. Bununla birlikte aynî toplanan gelirlerde kile farkı (tefâvüt) oranının yükselmesine rağmen vakfın elde ettiği toplam mahsulün önceki dönemlere nazaran az olması tarımsal nüfus ve üretimde bir artışın yaşanmadığını göstermektedir. $\mathrm{Bu}$ durum başlıca anbardan hububat satışlarından gelen diğer gelirler kaleminin düşük olmasına ve aynî maaş ve aylık ödemelerinin aksamasına neden olmaktadır. 1622 ve 1623 çok muhtemelen tarımsal üretimde ciddi düşüş yıllarıdır ve fiyatlar aşırı yükselmiştir. Buna rağmen vakfın mutfağı işlettiği ve maaşlar ile aylıkları ödeyebildiği görülmektedir. Ancak bütçe fazlası oluşmamakta ve nakdi teslimatlar bulunmamaktadır.

\section{1-1640 Dönemi}

1631 / 1040-1041 y1lı muhasebe defteri 163.000 akça devreden bakiye kaydetmektedir. Bunun içinden 118.000 akçalık alacak cari dönem içinde tahsil edilmiş 45.000 akça ise baki kalmıştır. İltizam gelirleri 441.500 akçadır. Bu gelir azalışının nedeni öncelikle Ereğlice'nin iltizam kayıtlarından 
çıkmasıdır. Gelibolu'daki hamam uzun yıllardır olduğu gibi 8.000 akçaya iltizam edilmiştir. Diğer gelirler kalemi 11.000 akça kadar ve yine düşüktür. Emanet usulü ile nakdi alınan vergilerden gelen gelirler de 68.000 akçaya inmiştir. Aynî tahsilat da 5.500 kile ile düşük seviyededir. Muhasebe dönemi aslında ondört ay kadar bir zamanı kapsadığından tamamı değilse de birçok maaş ödemesi bu dönem için yapılmıştır. Kendilerine nakdi veya aynî hiç ödeme yapılmamış bazı zevâ 'idhârân bulunmaktadır. Diğer giderler ile ücret ve tamirat giderleri bir miktar yüksektir. Bir önceki dönemden devreden ve cari yılda da tahsil edilemeden kalan 45.000 akçaya ilaveten cari dönemden kalan 73.500 akçalık alacak ile birlikte toplam alacaklar 118.500 akçaya ulaşmıştır. Vakıf dönemi 10.600 akça kadar açıkla kapamıştır. Anlaşıldığ 1 kadarı ile bu açık mütevelli Mustafa Ağa tarafından karşılanarak vakfa hibe edilmiştir.

İzleyen 1632 / 1041-1042 y1lında devreden 118.500 akça alacağın 103.500 akçası tahsil edilmiştir. İltizam gelirleri 496.000 akçaya yükselmiştir. Bu artış bir kere daha Ereğlice'nin bir mukataa olarak vakfa gelir getirmesidir. Hamam ve değirmenlerden gelen sirasıly 8.000 ve 5.000 akçalık iltizam gelirleri ile bazı gelirler diğer gelirler kalemi altına alınmıştır. Ayrıca hububat satışından 7.360 akça elde edilmiştir. Emanet usulü ile toplanan nakdi gelirler 75.000 akçaya çıkmıştır. Toplam 6.000 kile kadar da aynî tahsilat olmuştur. Bazı zevâ'idhârân'ın nakdi ve aynî aylıkları dışında maaş ve aylıklar ödenmiş ve mutfak işlemiştir. Diğer gider kalemlerinden sonra kalan 183.000 akçalık gelirin 60.000 akça kadarının vakfın bakımını üstlendiği camilerden birinin tamiri, müderrisin geçmiş maaşlarının ödenmesi ve veresiye et alımından kasaba olan borcun ödenmesine gittiği anlaşılmaktadır. Geriye kalan gelirin 117.600 akçası alacak olarak kaydedilmiştir. Böylece vakıf mali dönemi kesede 10.306 akça ile kapamıştır.

1633 / 1042-1043 yılında yaklaşık onbir ayı kapsayan hesap dönemi içinde önceki dönemden devreden alacağın tamamı tahsil edilmiştir. Defterin gelirler kısmının hemen başında 'an mahsûl-i müteferrika-i evkâf-ı mezbur başlığı altında 25.000 akçalık gelir kaydı yer almaktadır. İltizam gelirleri 438.000 akçaya gerilemiştir. Mukataa bölgelerinin çoğu, Ereğlice de dahil, $\% 20$ daha az bedelle iltizama verilebilmiştir. Hamam ve değirmen gelirleri mukataa gelirleri ile aynı başlık altında kayıtlıdır. Emanet ile toplanan nakdi gelirler 68.000 akçaya aynî gelirler ise yaklaşı 5.500 kileye inmiştir. Muhasebe dönemi bir tam yılı kapsamadığından maaş ödemeleri genelde onbir aylıkdır. Bazı maaşlar daha da kısa bir dönem için ödenmiştir. Sair harcamalar ile ücret ödemeleri ve tamirat giderleri düşmüştür. Vakıf tüm giderlerin kaydından sonra Gelibolu'daki eski caminin tamiri için 111.000 
akçalık bir tamirat masrafi üstlenmiştir. İlgili kayıt camiinin 1633 Mayıs ayında harap olduğunu belirtmektedir. Defter sonunda 143.250 akça alacak olarak kaydedilmiştir. Böylece dönem 30.550 akça açık ile kapanmıştır.

1634 / 1043-44 yılını içine alan muhasebe defteri onsekiz aylık bir dönemi kapsamaktadır. Devreden alacakların önemli bir kısmı tahsil edilmiş sadece 25.000 akçası kalmıştır. İltizam gelirleri 539.200 akçadır. Bu kez birçok mukataa bölgesi iltizam bedellerini \%25 oranında arttırmıştır. Emanet ile toplanan nakdi gelirler değişmemiştir. Vakıf 2.500 kile kadar hububat satarak 51.000 akça kadar gelir temin etmiştir. Aynî tahsil edilen gelirler ise 7.413 kiledir. Bu miktar önceki yıllara nazaran yüksek olmasına rağmen aslında kile fark1 (tefâvüt) oranı tüm ürünlerde 1 Edirne kilesi 2 İstanbul kilesi olacak şekilde değiştirilmiş görünmektedir. Maaş ödemeleri onsekiz aylık bir dönemi kapsadığından yüksektir. Kayıtlı yirmidört zevâ'idhârân'ın onikisi aylık almıştır. Mutfak giderleri de onsekiz aylık dönemi kapsadığından yüksektir. Bu giderler içinde en mühimi olan et satınalımı maliyeti 234.000 akçaya yaklaşmıştır ki bunun 223.000 akça kadarı veresiye alımdır.

Defter bundan sonra sair harcamalar ile ücret ödemelerini ve daha sonra tamirat giderlerini kaydeder. Burada hesaplar karışmaktadır. El-meremmât 46.665 akça olarak verilmesine karşın sadece 18.155 akçalık giderin dökümü verilmiştir. Hemen arkasından be-cihet-i meremmât kerden-i türbe ve mescid ve hânehâ-i şerîf girişi altında 45.665 akçalık tamirat gideri kayıtlıdır. Oysa harcamanın ayrıntılı dökümü ancak 7.000 akçayı bulmaktadır. Daha sonra harc-ı meremmât kerden-i minâre-i câmi ' $i-i$ şerîf der Lapseki girişi altında 11.965 akçalık gider dökümü verilmiştir. İzleyen kayıtlarda da çeşitli tamirat giderleri verilmiştir. Kısacası defterin kendi verdiği tamirat hesapları karışık ve toplam tamirat gideri rakamı tutarsizdir. Defter bu giderlerden sonra 12.000 akça baki kaydetmiştir. Bunun da 10.000 akçasının yeni mütevelli Osman Ağa'ya imaretin buğday parası için teslim edildiği ve geriye 2.000 akça kaldığı kayıtlıdır. Arkasından 52.000 akçaya ulaşan alacaklar kaydedilmiştir. Böylece vakıf dönemi 50.000 akça açıkla kapamıştır.

1635 / 1044-1045 y1l defteri önceki defterle uyumlu biçimde 62.000 akçalık devreden bakiye kaydetmiştir. Bunun 10.000 akçası kesede nakittir ve 52.000 akçası alacaklardır ki cari dönemde 27.000 akçası tahsil edilmiştir. Mukataa gelirleri 546.450 akçadır. Bu meblağın içinde 650 akçaya kiraya verilen kervansaray, 5.000 akçaya iltizam edilen değirmenler ve 8.000 akçaya kiraya verilen Gelibolu hamamı da yer almaktadır.

Gider kayıtları nakdi ve aynî maaş ve aylıkların ödendiğini ve mutfak giderlerinin karşılandığını göstermektedir. Giderler sonrasında 110.000 akça kadar bir gelir baki kaydedilmiş̧ir. Ancak bunun 45.000 akçası Bolayır'da 
camii ve imaretin tamiratına harcanmıș ve 85.000 akçası da Kavak kasabasındaki camiinin tamiratına sarfedilmiştir. Böylece sadece 440 akça kalmıştır. Ayrıca 25.000 akçalık alacak kaydından sonra dönem 24.560 akça açık ile kapatılmıştır.

1636 / 1045-1046 y1lında mukataa gelirleri değişmemiş̧ir. Emanet usulü ile toplanan nakdi ve ayni gelirlerde de önemli bir değişim yoktur. Kayıtlı 31 zevâ'idhârânın yirmialtısına tam ödeme yapıldığından maaş ve aylık ödemeleri toplamı biraz yüksek görünmektedir. Mutfak giderleri'nin kayıtları fiyatlar bakımından olağan kayıtlardan biraz daha detaylıdır. Et (guşt) ki defterde hataen dakik olarak kaydedilmiştir yedi ile on akça arasında dört ayrı fiyattan satın alınmıştır. Vakıf pazardan kilesi otuz ile kırk akça arasında dört ayrı fiyattan buğday da satın almıştır. Pirinç (erz-i mısrî) satın alımı ise oniki ayrı fiyat seviyesindendir. Fiyat men başına elli ile altmışsekiz akça arasındadır. Sadeyağ (revgân-1 sâde) men başına yüz ile yüzkırkdört akça arasında fiyatlardan dokuz seferde alınmıştır.

Sair harcamalar, ücretler ve tamirat giderlerinden sonra 52.000 akça kayıtlıdır. Bunun içinden müderrisin gecikmiş 7.200 akçalık maaşı ödenmiş, önceki dönemin 24.560 akçalık bütçe açığı kapanmış ve 25.000 akça da Hicri 1043 yllından kalan alacak olarak kaydedilmiştir. Böylece dönem 3.950 akça açık ile kapanmıştır.

1637 / 1046-1047 yılı defteri mukataa gelirlerini 528.850 akça olarak vermektedir. İstarine mukataası 66.000 akçadan 50.000'e, hamam kirası 8.000 'den 7.000 akçaya düşmüştür. Emanet ile toplanan nakdi gelirlerde önemli bir değişim yoktur. Aynî gelirler ise 7.000 kileye yükselmiştir. Kile farkı (tefâvüt) oranı buğdayda 1 Edirne kilesi 2 İstanbul kilesine eşit şekilde ayarlanmışken arpa ve yulafda düşmüştür. Maaş ödemeleri yapılmıştır ancak sadece onüç zevâ'idhârâna aylık ve dokuzuna aynî yardım ödenmiştir. Mutfak düzenli işlemeye devam etmiştir. Sair harcamalar kalemi 59.000 akça ile yüksek bir meblağa ulaşmıştır. Tamirat giderleri de 38.000 akça ile görece yüksektir. Buna karşın vakıf 44.457 akça bütçe fazlası elde etmiş ancak bunu teslim be rikâb-ı hümâyun 'an zevâîd-i evkâf-mezbûre kaydı ile teslim etmiştir.

1638 / 1047-1048 yılında mukataa gelirleri değişmemiştir. Emanet usulü ile toplanan nakdi gelirlerde de kayda değer bir değişim yoktur. Aynî gelirler ise 6.300 kileye inmiştir. Bunun 741 kilesi 29.640 akçaya satılmış kalanı anbara çekilmiştir. Ancak defterin başında gelecek dönem gelirlerinden Mürefte mukataasından 80.000 akça olmak üzere toplam 94.525 akçanın peşin tahsil edildiğine dair bir kayıt vardır. Dahası mütevellinin vakfa yardımı olarak 140.000 akça vakfın geliri olarak 
kaydedilmiştir. Bu gelirler ile vakıf olağan maaş ve aylık ödemelerini nakdi ve aynî olarak yerine getirmiş, mutfağ iş̧etmiş ve diğer giderleri karşılamış, dönem sonunda 217.000 akçayı "el-bâkî" olarak kaydetmiştir. Bu meblağdan 100.000 akça "teslîm hizâne-i Darü's-sa 'âde" kaydı ile teslim edilmiş ve geriye 117.000 akça vakfa kalmıştır.

\section{Genel Mali Görünüm (1631-1640)}

1631 yılında vakfin önceki dönemden devreden alacakların önemli bir kısmını tahsil etmesine karşılık yine de 45.000 akça alacak kaldığını ve cari y1ldan kaynaklanan alacaklarla birlikte dönem sonunda toplam alacağın 118.500 akçaya ulaştı̆̆ını görüyoruz. İzleyen yıl Ereğlice'nin iltizam gelirlerine katılması ile gelirler artmış, önemli miktarda alacak tahsil edilmiştir. Ancak cari dönemden büyük miktarda alacak kaldığından ve vakıf gecikmiş maaş ödemeleri ile borçları kapamak zorunda kaldığından büyük bir bütçe fazlası oluşmamıştır. 1633 yılında ise devreden alacakların tamamı tahsil edilmekle birlikte iltizam gelirleri ve aynî gelirler vakıf maliyesini sarsacak derecede düşmüştür. Üstelik pek muhtemel 1633 y1lı Mayıs ayında gerçekleşen yerel bir afet dolayısı ile vakıf ciddi tamirat masraflarını üstlenmek zorunda kalmıştır. 1634 yılında iltizam gelirlerinin yeniden artmasına karşılık vakfın yüksek tamirat masraflarını karşılamaya devam ettiği görülmektedir. Yüksek tamirat giderleri 1635 yılında da vakıf maliyesini etkilemektedir.

Vakfin mali durumunun 1637 y1lında tamirat masraflarının azalması ile rahatladığ1 ve hatta vakfın merkezi hazineye nakdi teslimatta bulunduğu görülmektedir. 1638 yılında da mütevellinin vakfa yardımı ve peşin iltizam bedeli tahsilatları ile vakfın dönem sonu fazlası 200.000 akçayı aşmış, bunun 100.000 akçası merkezi hazinelere teslim edilmiştir.

Dönem içerisinde tahsilat düzensizlikleri, yüksek tamirat giderleri, borçlanmalar ve bütçe açıklarına rağmen vakıf bazan veresiye alım ile bile olsa mutfağı işletmiş ve maaşları gecikmelerle de olsa ödemiştir.

\section{Değerlendirme}

Şehzade Gazi Süleyman Paşa vakfının ana gelir kaynağı kırsal gelirlerdir. Vakıf bu gelirlerin büyük kısmını iltizam yöntemi ile tahsil etmektedir. 17.yy'ın ilk yarısında bu gelirlerde ciddi bir tarımsal krizi gösteren bir azalış veya artış ortaya çıkmamıştır. Dönem boyunca bazı yıllarda önemli miktarda gelir tahsil edilemeden kalmış olsa bile, izleyen yıl bu gelirler tahsil edilebilmiştir. Dolayısı ile arka arkaya yaşanan ve tarımsal ekonomide bir krizi ima eden tahsilat güçlükleri görünmemektedir. 
Vakfın mukataa gelirlerinde 1609 yılında görülen düşüşün nedeni Ereğlice'nin mukataa gelirlerinin vakıfdan çekilmesidir. Vakfın toplam iltizam gelirlerini etkileyen en önemli unsurlardan biri Ereğlice'nin vakıf gelirleri içinde olup olmamasıdır. Ereğlice gelirleri aslında Süleyman Paşa'nın İznik medresesine tahsis edilmiştir. ${ }^{18}$ Ancak öyle görülüyor ki Bolayır' daki vakıf mali sıkıntı içine girdiğinde bu mukataanın gelirleri vakfa aktarılmaktadır.

Ereğlice mukataa bölgesi olmaksızın vakıf gelirlerinin 1610 yılında 442.000 akça seviyesine çıkması aslında tarımsal koşullarda bir iyileşmeye işaret eder. Ancak 1611 y1lında mukataa gelirlerinde \%10'a yaklaşan bir düşüş olmuş, gelirler 1610 yılındaki seviyesinden yaklaşık 412.000 akça seviyesine düşmüştür. Daha sonra kademe kademe yükselerek 1618 y1lında yeniden 440.000 akça seviyesini yakalamıştır. 1611 yılındaki düşüş aynı yıl üstlenilen yüksek tamirat masrafları da dikkate alındığında bir yerel afete işaret etmektedir. Aynı yıllarda Gelibolu'daki Saruca Paşa vakfı da yüksek tamirat masrafları üstlenmek zorunda kalmıştır. ${ }^{19} 1622$ yılında mukataa gelirlerinde görülen muazzam artış aslında Ereğlice'nin yeniden bir mukataa bölgesi olarak vakıf tarafından iltizam edilmesinden kaynaklanmaktadır. Aslında bu yıl vakfın tahsil ettiği mahsulün düşük olduğu ve fiyatların aşırı yüksek olduğu bir yıldır. Dolayısı ile tarımsal ekonomide bir üretim düşüşü olduğu ve vakfın mali açıdan zorlanacağı tahmin edilerek Ereğlice gelirleri yeniden vakfa tahsis edilmiş de olabilir. 1633 yılında Ereğlice de iltizam edilmiş olmakla birlikte toplam mukataa gelirleri düşüktür. Birçok mukataa bölgesinden gelirler azalmıştır. Bu yıllarda çok muhtemelen bir depremin etkilerini görmekteyiz. 1633-35 yılları arasında üstlenilen ve vakıf maliyesini zorlayan yüksek tamirat masrafları depremin yarattğ 1 tahribattan ileri geliyor olmalıdır. ${ }^{20}$ Diğer taraftan mukataa gelirleri 1634 yılı ile birlikte yeniden eski seviyesini yakalamış hatta geçmiştir.

Vakfin kervansaray ve dükkanlardan elde ettiği kira ve iltizam gelirlerinden bir sonuç çıkarmak maalesef olanaklı değildir. Vakfın Gelibolu'daki hamamının tamirata ihtiyacı olduğu bu nedenle vakfin 1606 yılında üçbuçuk yıllık peşin bedelle hamamı kiraya verdiği anlaşılmaktadır. 1609 ile 1610 yıllarında ise hamam ile çarşı dükkanları hâlî kalmıştır.

${ }^{18}$ Gökbilgin, Edirne ve Paşa Livası, s. 169.

${ }^{19}$ Kayhan Orbay, "The Waqf of Saruca Pasha in Gallipoli and Agricultural Economy in $17^{\text {th }}$ century Thrace", basilacak.

${ }^{20} 1632$ ve 1633 senelerinde Filibe'de Şehabeddin Paşa vakfı da çok yüksek tamirat masrafları üstlenmek zorunda kalmıştır. Kayhan Orbay ve Hatice Oruç, "Filibe'de Şehabeddin Paşa Vakfi 1632-1641 (H. 1041-1051)", basılacak. Gazi Süleyman Paşa vakfinın muhasebe defteri bu afeti 1633 yılı Mayıs ayına tarihlemektedir. 30 Temmuz 1633'e tarihlenen büyük bir deprem konusunda bkz., Nicholas Ambraseys, Earthquakes in the Mediterranean and Midle East, Cambridge, Cambridge University Press, 2009, s. 481. 
Sonrasında hamam düzenli olarak onlarca y1l boyunca senelik 8.000 akça bedelle kiraya verilmiştir.

Vakıf kırsal gelirlerinin bir kısmını kendi cabi ve katipleri eliyle toplamaktadır. $\mathrm{Bu}$ gelirlerin nakdi toplanan vergilerden oluşan kesimi 17.yy'in ilk çeyreğinden itibaren hafif bir düşüş göstermiştir. Ancak gelirlerdeki değişim yine de vergi mükellefi nüfusta ve vergiye konu olan ürünlerde ciddi bir gerilemeye işaret etmez.

Aynî toplanan gelirler ise yıldan y1la önemli dalgalanmalar gösteren istikrarsız bir gelir kalemidir. Yı1lık hasatın olağan tabiatından kaynaklanan istikrarsızlığ 1 vakıf gelir ve giderlerini de etkilemektedir. Hasatın bol olduğu yıllarda hububat fiyatları gerilemekle birlikte vakfın anbarında satarak nakite çevirebileceği ve böylece ek gelir temin edebileceği miktarda ürün olmaktadır. Dahası vakıf cari dönem içinde pazardan daha az hububat satın almakta ve sonraki döneme daha yüksek anbar mevcudu aktarabilmektedir.

Hasatın az olması yerel tarımsal ekonomide düşük tarımsal ürün ve dolayısıyla yüksek fiyatları ima etmektedir. Bu durumda vakıf hem hububat satışından gelen gelirlerden mahrum kalmakta hem de pazardan yüksek fiyattan hububat satın almak zorunda kalmaktadır. 1604 yılında olan da budur. Hububat mahsulü az olduğu gibi önceki dönemlerden vakfın tahsil edemediği aynî gelirleri bulunmaktadır. Cari yıldan da tahsil edilemeden kalan aynî gelirler olmuştur. Dolayısı ile vakfın anbar stokları da zayıfdır. 1605 ve 1606 yıllarında da mahsul az ve hububat fiyatları yüksektir. 1606 yılında vakfın buğday cinsinden borçlanmak zorunda kaldığını dahi görebilmekteyiz. Yine de 17.yy'ın ilk yarısında tarımsal ekonomide vakfı uzun dönemli bir mali krize sokacak gelişmeler tespit edilememiştir. 16041606 yılları ve 1622-23 yılları muhtemelen bölgesel tarımsal üretimin düştüğü yıllardır.

Vakfın gider kalemleri de belirli bir aralıktadır. Maaş ve aylık ödemeleri ancak vakıf herhangi bir mali güçlüğe düştüyse tam ödenmediğinden bir sonraki yıla devretmekte ve sonraki yıl veya yıllar için ek bir maliyet oluşturmaktadır. Aynı durum mutfak harcamaları için de geçerlidir. Nakdi ve aynî, maaş ve aylık ödemelerinde bazı aksamalar ortaya çıkmıştır. Mutfak giderlerinin kısmen veresiye alımlarla karşılıandığ 1 yılar da vardır. Buna rağmen 17.yy'ın ilk yarısında elimizdeki defterler vakıf çalışanlarının veya aylık alan kesimlerin sayıca azaltıldığı, maaş veya aylıkların tamamen kesildiği, mutfağın işlemediği hatta mutfak hizmetlerinin kısmen olsun daraltıldığı bir dönemi göstermemektedir.

Toplam giderler istisnai bazı ödemeler veya teslimatlar olmadıkça vakfı zorlamamaktadır. Vakıf ilk on yıl içinde bazı yıllarda Darüssaade Ağalığı Hazinesi'ne nakdi teslimatlarda bulunmaktadır. Sonraki 25 yıl ise teslimat 
kaydı yoktur. Vakıf bütçesi ciddi meblağlara ulaşmayan bütçe açıkları veya fazlaları vermektedir. Bir bakıma Ereğlice mukataasının getirdiği ek gelir, peşin tahsilatlar ve nakdi teslimatları yapmayarak hasatın düştüğü, alacak veya borçların biriktiği, afetlerin tamirat masrafları çıkardığı yılları dengelemektedir. Vakıf maliyesi ciddi bir krize girmemekle birlikte refah içinde de olmamıştır.

\begin{tabular}{|c|c|c|c|c|c|}
\hline & $\begin{array}{l}891^{21} \\
1486\end{array}$ & $\begin{array}{l}1012-13 \\
1604\end{array}$ & $\begin{array}{l}1013-14 \\
1605\end{array}$ & $\begin{array}{l}1014-15 \\
1606\end{array}$ & $\begin{array}{l}1015-16 \\
1607\end{array}$ \\
\hline Toplam Gelirler & 199.977 & 609.582 & 665.387 & 698.714 & 875.191 \\
\hline Devreden bakiye & 37.544 & 126.097 & 99.226 & 98.752 & 138.681 \\
\hline Bundan tahsil edilen & & 27.395 & & & 77.539 \\
\hline Peşin alınan & 0 & 97.500 & 17.584 & $\begin{array}{l}41.000+ \\
540 \text { kile } \\
\text { buğday }\end{array}$ & 56.000 \\
\hline Cari dönem geliri & & 385.990 & 598.597 & 558.962 & 680.510 \\
\hline Kira gelirleri & & 5.252 & 5.252 & 252 & 252 \\
\hline Çarşı dükkanları & & 252 & 252 & 252 & 252 \\
\hline Hamam & & 5.000 & 5.000 & peşin ${ }^{22}$ & peşin \\
\hline Kervansaray & & 700 & $(\ldots)$ & 800 & 800 \\
\hline Kervansaray dükkanları & & 213 & 213 & & \\
\hline Değirmenler & & 5.760 & 5.760 & 8.000 & 4.200 \\
\hline Mukataa gelirleri & & 377.360 & 366.160 & 464.546 & 419.500 \\
\hline Nakdi gelirler & & 77.952 & 77.592 & 75.901 & 76.838 \\
\hline Ayni gelirler (kile) & & 5.878 & 5.311 & 3.372 & 7.533 \\
\hline Diğer gelirler & & 33.926 & 99.233 & $\sim 14.000$ & 183.920 \\
\hline Toplam Giderler & 104.690 & 510.356 & 510.733 & 529.394 & 681.925 \\
\hline Maaş ödemeleri & 57.119 & 208.170 & 206.740 & 192.350 & 235.780 \\
\hline Daimi çalışanlar & & 145.770 & 146.890 & & 163.800 \\
\hline Zevâ'idharân & & 62.400 & \begin{tabular}{|l|}
59.850 \\
\end{tabular} & & 43.920 \\
\hline Mutfak giderleri & 35.467 & 254.821 & 254.236 & 286.470 & 377.388 \\
\hline Sair harcamalar & & 11.995 & 15.380 & 18.361 & 23.086 \\
\hline Ücret ödemeleri & & 18.272 & 14.581 & 18.280 & 20.628 \\
\hline Tamirat giderleri & 2.467 & 9.671 & 19.796 & 7.259 & 9.483 \\
\hline Diğer giderler ${ }^{23}$ & & & $109.500^{24}$ & & $82.340^{25}$ \\
\hline Teslimatlar $^{26}$ & & & & 42.480 & 45.000 \\
\hline Alacaklar & & 98.752 & 98.752 & 138.681 & 88.142 \\
\hline Kalan & 93.187 & 474 & 60 & -11.841 & 2.784 \\
\hline
\end{tabular}

21 Dokuz ayı kapsamaktadır.

22 Üç buçuk y1l için 17,584 akça peşin kira tahsilatı.

23 Borç ödemeleri, gecikmiş maaş ödemeleri ve benzerleri.

24 Eda-i mevacib. Vakfın gecikmiş maaş ödemeleri için büyük bir meblağ ödediği anlaşıllyor.

25 Borç ödemeleri, gecikmiş maaş ödemeleri ve benzerleri.

${ }^{26}$ Darüssaade Ağalı̆̆ı Hazinesi’ne. 


\begin{tabular}{|l|l|l|l|l|l|l|}
\hline & $\begin{array}{l}1017-18 \\
1609\end{array}$ & $\begin{array}{l}1018-19 \\
1610^{27}\end{array}$ & $\begin{array}{l}1019-21 \\
1611^{28}\end{array}$ & $\begin{array}{l}1021 \\
1612\end{array}$ & $\begin{array}{l}1025-27 \\
1617^{29}\end{array}$ & $\begin{array}{l}1027-28 \\
1618\end{array}$ \\
\hline Toplam Gelirler & & 601.277 & 887.199 & 514.788 & 607.785 & 547.198 \\
\hline Devreden bakiye & & 32.085 & 227.789 & & 86.571 & 5.765 \\
\hline $\begin{array}{l}\text { Bundan tahsil } \\
\text { edilen }\end{array}$ & & & 227.789 & & 77.665 & \\
\hline Peşin alınan & & & & & & \\
\hline Cari dönem geliri & 586.078 & 569.192 & 659.410 & & 521.214 & 537.433 \\
\hline Kira gelirleri & 0 & 0 & 3.000 & & & \\
\hline Çarş1 dükkanları & hâlî & hâlî & & & 830 & \\
\hline Hamam & hâlî & $h \hat{a} l \hat{\imath}$ & 3.000 & 8.000 & & 8.000 \\
\hline Kervansaray & 700 & 1.200 & 1.200 & 600 & & 460 \\
\hline Değirmenler & 4.670 & 3.235 & 2.310 & 3.270 & 3.270 & 3.270 \\
\hline Mukataa gelirleri & 423.370 & 441.935 & 412.010 & 418.170 & 433.770 & 440.230 \\
\hline Nakdi gelirler & 73.745 & 71.314 & 75.282 & 75.968 & 79.444 & 77.000 \\
\hline $\begin{array}{l}\text { Ayni gelirler } \\
\text { (kile) }\end{array}$ & 10.957 & 7.511 & 11.984 & 6.038 & 7.682 & 7.506 \\
\hline Diğer gelirler & 88.963 & 55.943 & 169.118 & 20.650 & 8.000 & $\sim 20.000$ \\
\hline $\begin{array}{l}\text { Toplam } \\
\text { Giderler }\end{array}$ & 553.993 & 325.728 & 851.266 & 347.262 & 595.140 & 527.578 \\
\hline Maaş ödemeleri & 208.710 & $127.590^{30}$ & $302.360^{31}$ & 118.020 & 297.745 & 234.030 \\
\hline Daimi çalışanlar & 164.430 & 100.320 & 232.920 & 89.460 & 210.855 & 171.690 \\
\hline Zevấ'idharân & 44.280 & 27.270 & 69.440 & 28.560 & 76.890 & 62.340 \\
\hline Mutfak giderleri & 292.891 & 171.390 & 368.150 & 147.528 & 268.342 & 255.387 \\
\hline Sair harcamalar & 19.695 & 5.979 & 25.020 & 35.839 & 16.625 & 17.507 \\
\hline Ücret ödemeleri & 24.217 & 16.038 & 34.666 & 13.987 & 18.246 & 17.327 \\
\hline Tamirat giderleri & 8.480 & 4.731 & 121.077 & 45.855 & 4.182 & 3.327 \\
\hline Diğer giderler ${ }^{32}$ & & & $41.120^{33}$ & $9.187^{34}$ & $2.880^{35}$ & $12.620^{36}$ \\
\hline Teslimatlar ${ }^{37}$ & & 57.000 & & & & \\
\hline Alacaklar & & 227.789 & & 157.557 & 8.906 & 7.000 \\
\hline Kalan & 32.085 & & & 782 & 859 & \\
\hline & & & & & & \\
\hline
\end{tabular}

27 Sekiz ayı kapsamaktadır.

28 Onaltı ayı kapsamaktadır.

29 Onbeș ayı kapsamaktadır.

30 Sekiz ayı kapsamaktadır.

31 Onaltı ayı kapsamaktadır.

32 Borç ödemeleri, gecikmiş maaş ödemeleri ve benzerleri.

33 Borç ödemeleri, gecikmiş maaş ödemeleri.

34 Borç ödemeleri.

35 Borç ödemeleri.

36 Borç ödemeleri.

37 Darüssaade Ağalı̆̆ı Hazinesi’ne. 


\begin{tabular}{|l|l|l|l|l|l|}
\hline & $\begin{array}{l}1028-29 \\
1619\end{array}$ & $\begin{array}{l}1029-30 \\
1620^{38}\end{array}$ & $\begin{array}{l}1031 \\
1622^{39}\end{array}$ & $\begin{array}{l}1031-32 \\
1622-23^{40}\end{array}$ & $\begin{array}{l}1035 \\
1625^{41}\end{array}$ \\
\hline Toplam Gelirler & 676.139 & 543.830 & 637.680 & 402.670 & 148.094 \\
\hline Devreden bakiye & 7.000 & 88.150 & 23.100 & 402.670 & 148.094 \\
\hline $\begin{array}{l}\text { Bundan tahsil } \\
\text { edilen }\end{array}$ & & 80.550 & & 392.170 & 148.094 \\
\hline Peşin alınan & 114.000 & & & & \\
\hline Cari dönem geliri & 555.139 & 455.680 & 614.580 & & \\
\hline Kira gelirleri & & & & & \\
\hline Çarşı dükkanları & & & & & \\
\hline Hamam & 8.000 & 8.000 & 8.000 & 4.000 & \\
\hline Kervansaray & 460 & 500 & 500 & & \\
\hline Değirmenler & 3.270 & 3.270 & 9.870 & 9.870 & \\
\hline Mukataa gelirleri & 446.230 & 456.270 & 536.370 & & \\
\hline Nakdi gelirler & 77.000 & 72.110 & 78.210 & & 7.843 \\
\hline $\begin{array}{l}\text { Ayni gelirler } \\
\text { (kile) }\end{array}$ & 8.330 & 4.417 & & 5.029 & \\
\hline Diğer gelirler & $\sim 32.000$ & 11.300 & & & \\
\hline Toplam Giderler & 587.989 & 424.240 & 264.309 & 530.950 & 149.977 \\
\hline Maaş ödemeleri & 253.890 & $143.235^{42}$ & $76.440^{43}$ & $173.480^{44}$ & $71.145^{45}$ \\
\hline Daimi çalışanlar & 185.730 & 124.065 & & 113.280 & \\
\hline Zevấ'idharân & 68.250 & 19.170 & & 36.480 & \\
\hline Mutfak giderleri & 271.985 & 202.836 & 170.685 & 329.762 & \\
\hline Sair harcamalar & 38.463 & 30.446 & 5.805 & 17.913 & 3.565 \\
\hline Ücret ödemeleri & 19.790 & 16.702 & 1.925 & 5.670 & 120 \\
\hline Tamirat giderleri & 3.861 & 15.391 & 2.854 & 4.125 & \\
\hline Diğer giderler ${ }^{46}$ & & & & & \\
\hline Teslimatlar ${ }^{47}$ & & & & & \\
\hline Alacaklar & 33.150 & 115.390 & 402.670 & 10.500 & \\
\hline Kalan & 55.000 & 4.200 & -29.299 & 170 & \\
\hline & & & & & \\
\hline
\end{tabular}

38 Dokuz buçuk ayı kapsamaktadır.

39 Yaklaşık dört ayı kapsamaktadır.

40 Sekiz buçuk ayı kapsamaktadır.

${ }^{41}$ Yaklaşı beş ayı kapsamaktadır.

42 Dokuz ayı kapsamaktadır.

43 Dört ayı kapsamaktadır.

44 Sekiz ayı kapsamaktadır.

45 Dört ayı kapsamaktadır.

46 Borç ödemeleri, gecikmiş maaş ödemeleri ve benzerleri.

47 Darüssaade Ağalığı Hazinesi’ne. 


\begin{tabular}{|c|c|c|c|c|c|}
\hline & $\begin{array}{l}1037-38 \\
1628\end{array}$ & $\begin{array}{l}1040-41 \\
1631\end{array}$ & $\begin{array}{l}1041-42 \\
1632\end{array}$ & $\begin{array}{l}1042-43 \\
1633\end{array}$ & $\begin{array}{l}1043-44 \\
1634^{48}\end{array}$ \\
\hline Toplam Gelirler & 558.850 & 684.250 & 737.860 & 648.600 & 827.158 \\
\hline Devreden bakiye & & 163.000 & 118.500 & 117.600 & 168.250 \\
\hline $\begin{array}{l}\text { Bundan tahsil } \\
\text { edilen }\end{array}$ & & 118.000 & 103.500 & 117.600 & 143.250 \\
\hline \multicolumn{6}{|l|}{ Peşin alınan } \\
\hline Cari dönem geliri & 558.850 & 521.250 & 594.360 & 506.000 & 658.908 \\
\hline \multicolumn{6}{|l|}{ Kira gelirleri } \\
\hline \multicolumn{6}{|l|}{ Çarşı dükkanları } \\
\hline Hamam & 8.000 & 8.000 & 8.000 & 8.000 & 8.000 \\
\hline \multicolumn{6}{|l|}{ Kervansaray } \\
\hline Değirmenler & 5.000 & 5.500 & 5.000 & 4.000 & 4.000 \\
\hline Mukataa gelirleri & 479.200 & 441.500 & 496.000 & 438.000 & 539.200 \\
\hline Nakdi gelirler & 70.600 & 68.000 & 75.000 & 68.000 & 68.500 \\
\hline $\begin{array}{l}\text { Ayni gelirler } \\
\text { (kile) }\end{array}$ & 6.737 & 5.499 & 6.048 & 5488,5 & 7.413 \\
\hline Diğer gelirler & 9.050 & 11.250 & 16.000 & & 51.208 \\
\hline Toplam Giderler & 551.244 & 576.354 & 555.094 & 424.900 & 815.158 \\
\hline Maaş ödemeleri & 265.230 & 263.340 & 255.385 & $217.650^{49}$ & $352.380^{50}$ \\
\hline Daimi çalışanlar & 214.740 & 219.510 & 217.305 & 198.840 & 328.680 \\
\hline Zevâ'idharân & 50.400 & 43.830 & 37.990 & 18.810 & 23.700 \\
\hline Mutfak giderleri & 233.155 & 252.269 & 252.512 & 197.691 & $349.657^{51}$ \\
\hline Sair harcamalar & 18.399 & 17.960 & 17.814 & 3.664 & 67.456 \\
\hline Ücret ödemeleri & 17.200 & 23.694 & 17.630 & 4.400 & 20.512 \\
\hline Tamirat giderleri & 19.260 & 19.091 & 11.753 & 1.495 & 46.665 \\
\hline Diğer giderler $^{52}$ & & & $59.860^{53}$ & $111.000^{54}$ & 10.000 \\
\hline \multicolumn{6}{|l|}{ Teslimatlar $^{55}$} \\
\hline Alacaklar & & 118.500 & 117.600 & 143.250 & 52.000 \\
\hline Kalan & 7.606 & -10.604 & 10.306 & -30.550 & -50.000 \\
\hline
\end{tabular}

48 Onsekiz ayı kapsamaktadır.

49 Onbir ayı kapsamaktadır.

50 Onsekiz ayı kapsamaktadır.

51 Onsekiz ayı kapsamaktadır.

52 Borç ödemeleri, gecikmiş maaş ödemeleri ve benzerleri.

53 Borç ve gecikmiş maaş ödemeleri ile tamirat masraflarını da içermektedir.

54 Tamirat harcamaları.

55 Darüssaade Ağalığı Hazinesi’ne. 


\begin{tabular}{|l|l|l|l|l|l|}
\hline & $\begin{array}{l}1044-45 \\
1635\end{array}$ & $\begin{array}{l}1045-46 \\
1636\end{array}$ & $\begin{array}{l}1046-47 \\
1637\end{array}$ & $\begin{array}{l}1047-48 \\
1638\end{array}$ & $\begin{array}{l}1059-60 \\
1649\end{array}$ \\
\hline Toplam Gelirler & 679.726 & 641.776 & 738.376 & 862.541 & 690.500 \\
\hline Devreden bakiye & 62.000 & 25.000 & & & \\
\hline $\begin{array}{l}\text { Bundan tahsil } \\
\text { edilen }\end{array}$ & 37.000 & & & & \\
\hline Peşin alınan & & & & 94.525 & \\
\hline Cari dönem geliri & 617.726 & 616.776 & 738.376 & 628.016 & 573.500 \\
\hline Kira gelirleri & & & & & \\
\hline Çarşı dükkanları & & & & & \\
\hline Hamam & 8.000 & 8.000 & 7.000 & 7.000 & 8.000 \\
\hline Kervansaray & 650 & 650 & 400 & 400 & \\
\hline Değirmenler & 5.000 & 5.000 & 5.000 & 5.000 & 5.000 \\
\hline Mukataa gelirleri & 546.450 & 546.250 & 528.850 & 528.850 & 507.500 \\
\hline Nakdi gelirler & 71.276 & 70.526 & 69.529 & 69.526 & 66.000 \\
\hline $\begin{array}{l}\text { Ayni gelirler } \\
\text { (kile) }\end{array}$ & 5.918 & 5.834 & 7.008 & 6.304 & 5.334 \\
\hline Diğer gelirler & & & & & \\
\hline Toplam Giderler & 569.286 & 609.166 & 763.919 & 645.541 & 572.623 \\
\hline Maaş ödemeleri & 279.120 & 296.280 & 264.960 & 217.040 & 280.800 \\
\hline Daimi çalışanlar & 226.800 & 234.440 & 229.320 & 200.000 & \\
\hline Zevấ 'idharân & 51.120 & 61.920 & 35.640 & 18.610 & \\
\hline Mutfak giderleri & 238.430 & 278.033 & 284.117 & 277.780 & 191.352 \\
\hline Sair harcamalar & 20.690 & 29.004 & 59.097 & 40.037 & 56.646 \\
\hline Ücret ödemeleri & 18.833 & 2.383 & 17.439 & 16.789 & 18.655 \\
\hline Tamirat giderleri & 9.333 & 3.466 & 38.366 & 30.543 & 25.170 \\
\hline Diğer giderler ${ }^{57}$ & $110.000^{58}$ & $31.560^{59}$ & & & \\
\hline Teslimatlar ${ }^{6}$ & & & & 100.000 & 117.000 \\
\hline Alacaklar & 25.000 & 25.000 & & & \\
\hline Kalan & 24.560 & -3.950 & 74.457 & 117.000 & 877 \\
\hline & & & & & \\
\hline & & & & \\
\hline
\end{tabular}

56 Beray-i 'avâîd-i mütevelli.

57 Borç ödemeleri, gecikmiș maaş ödemeleri ve benzerleri.

58 Tamirat harcamaları.

59 Borç ödemeleri.

${ }^{60}$ Darüssaade Ağalığı Hazinesi'ne. 


\section{Kaynakça}

AMBRASEYS, Nicholas, Earthquakes in the Mediterranean and Midle East, Cambridge, Cambridge University Press, 2009,

AYVERDİ , Ekrem Hakkı, "Gaazi Süleyman Paşa Vakfiyesi ve Tahrir Defterleri”, Vakıflar Dergisi, VII, 1968, 19-28.

BARKAN, Ömer Lütfi, "Edirne ve Civarındaki Bazı İmaret Tesislerinin Y1llı Muhasebe Bilançoları", Türk Tarih Belgeleri Dergisi, I/2, 1964, 235-377.

FAROQHI, Suraiya, "A Great Foundation in Difficulties: or some evidence on economic contraction in the Ottoman Empire of the mid-seventeenth century", Revue D'Histoire Magrebine, 47-48, 1987, 109-121.

FAROQHI, Suraiya, "Agricultural Crisis and the Art of Flute-Playing: The Wordly Affairs of the Mevlevi Dervishes (1595-1652)", Turcica, XX, 1988, 43-69.

GÖKBİLGİN, M. Tayyib, Edirne ve Paşa Livası, İstanbul, Üçler Basımevi, 1952.

GÜRAN, Tevfik, Ekonomik ve Mali Yönleriyle Vakıflar, İstanbul, Kitabevi, 2006.

Jennings Ronald C., "Pious Foundations in the Society and Economy of Ottoman TRABZON, 1565-1640. A Study Based on the Juridical Registers 'Şer'i Mahkeme Sicilleri' of Trabzon", Journal of the Economic and Social History of the Orient, vol. XXXIII, 1990, 271-336.

ORBAY, Kayhan, “16. ve 17. Yüzyıllarda Bursa Ekonomisi: Sultan Çelebi Mehmed Yeşil İmaret'inin Mali Tarihi (1553-1650)", A.Ü. Osmanlı Tarihi Araştırma ve Uygulama Merkezi (OTAM) Dergisi, no: 22, 2007, 125-158.

ORBAY, Kayhan, "Financial Consequences of Natural Disasters in Seventeenth-Century Anatolia: A Case Study of the Waqf of Bâyezîd II", International Journal of Turkish Studies, vol. 15, no. 1-2, 2009, 63-82.

ORBAY, Kayhan, "Financial Development of the Waqfs in Konya and Agricultural Economy in the Central Anatolia (Late $16^{\text {th }}-$ Early $17^{\text {th }}$ Centuries)", Journal of the Economic and Social History of the Orient, basilacak.

ORBAY, Kayhan, "The Waqf of Saruca Pasha in Gallipoli and Agricultural Economy in $17^{\text {th }}$ century Thrace", basilacak.

ORBAY, Kayhan ve Hatice Oruç, "Filibe'de Şehabeddin Paşa Vakfi 1632-1641 (H. 10411051)", basılacak, I.Ü. Edebiyat Fak. Güney-Doğu Avrupa Araştırmaları Dergisi. 
